\title{
Evaluation of cognitive load in team sports: literature review
}

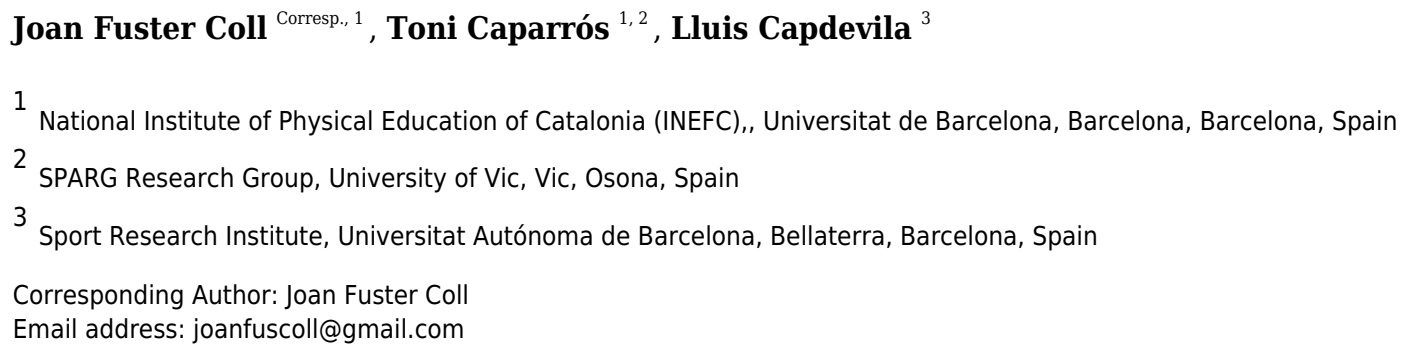

In team sports, load management has become one of the most common areas of investigation, given that effective control over load is the key to being able to optimize performance and avoid injuries. Despite the constant evolution and innovation in the latest theories, we can see a clear tendency in load management that focuses on physiological and mechanical aspects and neglects its cognitive character, which generates the variability inherent in the performance of athletes in a changing environment. Indicators of response that inform methods of control over cognitive load can include cognitive, physiological and behavioral indicators. However, limited investigations exist to support the reliability of each indicator regarding cognitive load. For this reason, the objective of this literature review is to present strategies used to manage cognitive load in team sports, as well as the indicators utilized for such a proposition and their relationships in specific contexts. 


\section{Evaluation of Cognitive Load in Team Sports:}

\section{Literature Review}

3

4

5

6

7

8

\section{Joan Fuster Coll ${ }^{1}$, Toni Caparrós ${ }^{1,2}$, Lluis Capdevila ${ }^{3}$}

${ }^{1}$ National Institute of Physical Education of Catalonia (INEFC), University of Barcelona (UB), Barcelona, Spain.

${ }^{2}$ SPARG Research Group, University of Vic, Osona, Spain.

${ }^{3}$ Sport Research Institute, Autonomous University of Barcelona (UAB), Bellaterra (Barcelona), Spain.

Corresponding Author:

Joan Fuster ${ }^{1}$

C/Bailen 149 2n 3a, Barcelona, 08037, Spain

Email address: joanfuscoll@gmail.com

\section{Abstract}

In team sports, load management has become one of the most common areas of investigation, given that effective control over load is the key to being able to optimize performance and avoid injuries. Despite the constant evolution and innovation in the latest theories, we can see a clear tendency in load management that focuses on physiological and mechanical aspects and neglects its cognitive character, which generates the variability inherent in the performance of athletes in a changing environment. Indicators of response that inform methods of control over cognitive load can include cognitive, physiological and behavioral indicators. However, limited investigations exist to support the reliability of each indicator regarding cognitive load. For this reason, the objective of this literature review is to present strategies used to manage cognitive load in team sports, as well as the indicators utilized for such a proposition and their relationships in specific contexts.

\section{Keywords:}

sport psychology, load management, athlete's health, cognitive affordances

\section{Introduction}

Team sports have a dynamic and complex nature (Lord et al., 2020). The players perform intermittent, high-intensity activities such as repeated sprints, jumps, impacts, fights, changes of direction, accelerations and decelerations during training and competition (Palauskas, 2019). In this regard, cognitive requirements are also considered crucial for optimal performance. These short, intense actions generally last less than 3 seconds, with moderate and long recovery periods (Ben Abdelkrim et al., 2007), and should be integrated into training strategies to promote 
40

41

42

43

44

45

46

47

48

49

50

51

52

53

54

55

56

57

58

59

60

61

62

63

64

65

66

67

68

69

70

71

72

73

74

75

76

77

78

79

adaptations that efficiently optimize athletic performance (Schelling, 2013) through interaction with the training load.

Traditionally, planning for training and competition has centered on the management of physiological and mechanical aspects, defined as internal load (IL) and external load (EL), respectively. IL and EL are related, the first being defined as the individual psychophysiological response and the second as the external physical stimulus applied to the athlete during training or competition (Soligard et al., 2016). This process can be assessed by the control and management of certain indicators that could offer information about the load effect on the athletes. (Soligard et al., 2016). In this context, however, the other elements that can affect the success of the athlete's training are neglected; for example, the quantification of the cognitive effort (Mujika, 2018), defined as the volitional assignment of resources in order to respond to the demands imposed by a task. Depending on the degree of effort involved, cognitive resources can be exhausted which can cause mental fatigue, a psychobiological state provoked by prolonged periods of demanding cognitive activity (Job y Dalziel, 2001). Furthermore, Van Cutsem et al. (2017) and Brown et al. (2020) conclude in their respective systematic reviews that cognitive effort causes a negative effect on physical performance.

Therefore, we consider that the cognitive load will be the relative amount of available mental resources that are invested in the resolution of a task. Cognitive load can be varied by changing the complexity of the assigned task but increasing its complexity will not involve a real increase of the individual's load if they do not employ enough effort to solve it (Cárdenas, 2015). For this reason, various authors describe how cognitive load is closely related to the emotional state of the athlete (Camacho et al., 2020; Cárdenas et al., 2013; Cárdenas, 2015; Rottenberg y Gross, 2003; Vaughan et al., 2018). The regulation of these emotions involves processes through which individuals influence their emotions. These processes require effort, thereby draining cognitive resources (Schmeichel, 2007).

Team athletes perform in a high-entropy environment that causes them to constantly expend mental resources to respond to the demands of the tasks, which requires significant mental effort (Cárdenas, 2015). Furthermore, deliberate constant evaluation of the possible alternatives during a game can consume the resources of the system and promote fatigue, impairing performance (Marcora et al., 2009). This cognitive demand combined to the effects of the internal and external load, can cause a maladaptation or rejection of the suggested load. This will directly influence whether the athlete is physically and/or mentally prepared for exposure to another training stimulus, known as the readiness to train/compete (Gabbett, 2017).

Cognitive load, together with its emotional dimension (Alarcón et al., 2018), requires structured planning and management that is complimentary with that of the physical load, providing information about how the planned sessions are being received. Other authors, such as Camacho 
80

81

82

83

84

85

86

87

88

89

90

91

92

93

94 95

96

97

98

99

100

101

102

103

104

105

106

107

108

109

110

111

112

113

114

115

116

117

118

et al. (2020), Cárdenas (2015), Gabbett (2010) and García-Calvo et al. (2019) agree with this reasoning. The main reason is that mismanagement of this load generates not only short-term effects, such as loss of performance (Sansone et al., 2020), reduction of technical abilities (Gantois et al., 2019) or loss of control over the real impact of the session (McLaren et al., 2016); but also, long-term effects, such overtraining or burnout (Goodger et al., 2007).

Including this parameter in training plans will be key to balancing the readiness of the athletes, achieving optimal performance and preventing injuries. The team sports environment requires intense and constant cognitive activity (Figueira et al., 2019), employing various brain mechanisms to adapt to a changing environment (Coutinho et al., 2017). In fact, there is a need to include specific, suitable and objective information for successful planning (Gabbett, 2010), as well as the control of the cognitive load of training (Gonçalves et al., 2017) and to define properly the variables involved on this process (Soligard et al., 2016). To this end, the current review aims to show, in a practical way, the strategies for the management of cognitive load in team sports, as well as the indicators used to monitor the load and the ways they are related in specific contexts.

\section{Survey methodology}

\section{Information sources}

A search of the literature between 1970 and 2020 was performed using the following online databases: Medline (PubMed), SPORTDiscus, PsycINFO and Google Scholar system. The following keywords were used: team sports, cognitive load, mental load, psychological load, workload, mental fatigue, cognitive fatigue, psychological fatigue, together with Boolean operators such as "AND" and "OR". Furthermore, this literature review was performed in accordance with the Preferred Reporting Items for Systematic Reviews and Meta-Analyses (Stewart et al., 2015).

\section{Criteria of inclusion of the study}

The titles and abstracts of all the articles were analyzed to determine the relevance of the publications for inclusion. Selection criteria for the articles were followed. The complete text of the publication was obtained to determine if it met the criteria for inclusion. In addition, the bibliographies of the selected articles were analyzed to find other relevant articles. Finally, for the current review, only those studies that are centered on the management of cognitive, mental or psychological load (in relation to the workload) and/or the ones that analyzed cognitive, mental or psychological fatigue (the effect on work and performance) in the specific context of team sports, were included. Therefore, those articles that try to quantify the individual cost of mental resources, given some capabilities, while achieving a given level of performance in a task with specific demands were included.

\section{Criteria of exclusion of the study}


119 Individual sports and studies in situations far from sports reality were excluded, as well as analyses

120

121

122

123

124

125

126

127

128

129

130

131

132

133

134

135

136

137

138

139

140

141

142

143

144

145

146

147

148

149

150

151

152

153

154

155

156

157

in laboratory situations. Duplicate articles were eliminated and summaries, non-peer reviewed works, book chapters and opinion articles were also excluded. As a first step, the titles, abstracts and key words screening of the literature was carried out by the authors. In the second step, fulltext articles of the relevant studies were screened while in the third step, the reference lists of the suitable articles and the review articles on the management of cognitive, mental or psychological load and/or fatigue were searched for additional articles. Any disagreement was discussed until consensus was reached.

\section{Results}

The initial literature search found 28851 articles related to cognitive load, but only 1947 were selected based on their title and abstract. After determining the content of the complete text, 1926 articles were excluded for being unrelated or incompatible with the inclusion criteria, or both (Figure 1). A total of 22 studies were included, which described the management of cognitive load in different situations. These, following the classification of indicators described by Capdevila (2001), were classified depending on the type of indicator of response analyzed, discriminating between cognitive (Table 1), a set of subjective indicators collected in a sporting situation, usually from written tests such as questionnaires, tests or self-reports; physiological (Table 2), indicators obtained with the aid of apparatus allowing the analysis of physiological or biochemical parameters; and behavioral (Table 3), indicators of the analysis of the observable behavior of the athlete, usually external motor behavior or verbal behavior.

\section{Discussion}

The authors use different methods to manage cognitive load, analyze specific and applicable information, exercise better control over training and optimize performance. To do so, they try to quantify, through indicators, the individual cost of mental resources, given certain capacities, while reaching a certain level of performance in a task with specific demands. Cognitive load management methods can be used before, during or after task performance. These cognitive load management methods are based on the analysis of these response indicators, usually classified as cognitive, physiological and behavioral indicators (Capdevila, 2001), so this review will address all three types.

\section{Cognitive indicators}

\section{NASA-TLX}

The NASA-TLX questionnaire has proven sensitive to the mental load in a variety of cognitively demanding tasks, such as piloting an aircraft or laboratory tasks (Luque-Casado et al., 2016). This scale analyses the subjective perceived work according to six dimensions: mental demand (perceptive and mental effort), physical demand (degree of physical activity), temporal demand (perceived pressure related to decision-making speed), effort (the combination of the mental and 
158

159

160

161

162

163

164

165

166

167

168

169

170

171

172

173

174

175

176

177

178

179

180

181

182

183

184

185

186

187

188

189

190

191

192

193

194

195

196

197

physical effort needed) and frustration (the negative emotions perceived). This offers an overall score of the workload (from 0 to 100 points, a.u.) based on the average of the six dimensions.

In all studies analysed, the NASA-TLX questionnaire was significantly sensitive to changes in the cognitive load in different team sports situations. In tasks that involve mental fatigue, significant differences are shown between the control and experimental groups (Alarcón et al., 2017; 2018). In the study by Camacho et al. (2020) performance on training tasks under temporal and quantityof-technical-movement restrictions was analysed and the most specific management tool for the increased cognitive load was the NASA-TLX. Likewise, García-Calvo et al. (2019) also used this tool to identify the increase of the cognitive load as a function of the modification of the scoring system.

Measurement Period: After the session/competition

\section{0mm VAS (MF and ME)}

The VAS scale (Visual Analogue Scale) offers specific information about a characteristic or attitude which is identified along a continuum of values and cannot easily be directly measured (Gould et al., 2001). It has a unidimensional format, charted in a 100mm straight line, with limits identified as the perceived minimum (0) and maximum (100). The subjects only need to make a mark on the line that indicates their relative perception of their current situation. The distance will be measured in millimeters (from left to right) and this will be the subjective reference value.

This tool has been used frequently in the bibliography to describe the fatigue and lack of energy caused by a cognitively demanding activity (mental fatigue, MF) and/or the degree of effort employed to perform a cognitively demanding activity (mental effort, ME). It has been proved that the scale is a valid, reliable method to measure both MF and ME (Lee et al., 1991).

The first investigations demonstrated that the increase of perceived indicator VAS MF damaged specific technical performance (Smith et al., 2016; Badin et al., 2016). In Badin's study (2016), effects of VAS MF on physical abilities were not found, in contrast to subsequent studies which related VAS MF to the loss of both technical and physical abilities (Veness et al., 2017; Coutinho et al., 2017; 2018). Sansone (2020) adds that within this loss of abilities, offensive tasks cause more significant VAS MF and ME than defensive tasks. Differing a bit from what has been previously described, Kunrath (2020) shows that VAS MF reduces technical, tactical and cognitive abilities, provoking a compensatory improvement of the performance.

Measurement Period: After the session/competition

\section{CSAI-2}

CSAI-2 (Competitive State Anxiety Inventory 2) is a test that aims to estimate the cognitive and somatic anxiety levels of the players, as well as their levels of self-confidence. Cognitive anxiety refers to the negative feelings that the subject has about his or her performance and the consequences of the outcome. Somatic anxiety, on the other hand, refers to the perception of 
198

199

200

201

202

203

204

205

206

207

208

209

210

211

212

213

214

215

216

217

218

219

220

221

222

223

224

225

226

227

228

229

230

231

232

233

234

235

236

physiological indicators of anxiety such as muscle tension, increased heart rate, sweating and stomach discomfort. It has a questionnaire format consisting of 27 items, with 9 items for each subscale. Each of them is classified on a 4-point Likert-type scale, which yields scores from 9 to 36 in each subscale. A higher score related to cognitive and somatic anxiety indicates a higher level of anxiety (Martens et al., 1990).

Arruda et al. (2017) study suggests that cognitive anxiety increases as a function of the level of the opponent, causing more psychological stress. Furthermore, it highlights that cognitive anxiety increases exponentially depending on the rival, more than somatic anxiety. This information could offer an approximation to the concept of cognitive load, dissociating the somatic state from the cognitive one.

Measurement Period: After the session/competition

\section{POMS}

The POMS (Profile of Mood States) questionnaire was proposed by McNair, Losr and Droppleman (1971) with the aim of evaluating the mental fatigue related to physical effort. The questionnaire is classified on a Likert scale and it contains 65 items that provide measures of six specific mood states: tension, depression, anger, vigor, fatigue and confusion. These factors can be combined to create a compound measurement of mood state by adding the five negative factors and subtracting the positive factor of vigor. Further, a 100-point baseline score is added to prevent negative scores (Raglin et al., 1991).

It has been proved that POMS is a reliable and valid questionnaire to measure affective features, mood state and emotions (Lin et al., 2014). That is why Mashiko et al. (2004) use it as a test of mood state in order to evaluate mental fatigue. In their study they could observe significant changes between different game positions in rugby games, obtaining important differences between the relation of mental and physical fatigue.

Measurement Period: After the session/competition

\section{Cognitive RPE}

The RPE (rating of perceived exertion) is a valid method for quantification of the effort expended in an athletic training activity during a wide variety of exercise types (Foster et al., 2001). Depending on the question the athlete is asked, distinctive subjective variables can be measured. These differential ratings of perceived exertion (dRPE) can provide additional information to that obtained by a single measurement (Gil-rey et al., 2015). In this review, we focus on cognitive RPE (RPE-T in the classification of dRPE), which is the one that answers the question "How much mental effort and decision-making has this task required?" To quantify it, two scales are used, CR100, also known as "centiMax", (Borg et al., 2001), scored from 0 to 100 and CR-10 (Borg et al., 1985), varying from no exertion (0) to maximum effort, such as a competition (10). The important 
237

238

239

240

241

242

243

244

245

246

247

248

249

250

251

252

253

254

255

256

257

258

259

260

261

262

263

264

265

266

267

268

269

270

271

272

273

274

275

276

difference between them is that the CR-10 uses whole numbers corresponding to verbal anchors and the CR-100 does not (Fanchini et al., 2015).

In Farrow et al., (2008) study it was shown that cognitive RPE (CR-10) was sensitive to tasks that involved increased decision-making in game-like situations. Having followed this line of research and found results that agree with the mentioned study, Gabbett et al. (2010) justify the use of cognitive RPE as valid for control of cognitive load, but since it is a subjective measurement it would require more objective methods to be compared and measured. In order to relate the subjective data obtained to some objective data, McLaren (2016) finds strong associations between RPE-T multiplied by the session time (sRPE-T) and the tasks focused on speed and specific abilities, the latter being open tasks focused on the game. This RPE-T increases significantly when the game is against the top teams of the league (Barrett et al., 2018). Therefore, we can say that according to the results of these four studies, cognitive RPE is sensitive to open tasks that seek to replicate the competitive game, creating an uncertain environment.

Measurement Period: After the session (recommended 15-30' later)

\section{SIATE / VSC}

SIATE (Sistema Integral de Analisis de Tareas de Entrenamiento, from its Spanish initials) and VSC (Valoración Subjetiva de la Carga, from its Spanish initials) are ecologic systems for quantifying the load of a basketball training session (Valles et al., 2017; Reina et al., 2019). They are intended to provide a holistic view of training, taking into account more than just internal and external load.

Ibáñez et al. (2016), in order to quantify training using direct observations, designed a methodological system to register and subsequently analyze different factors that are relevant to the athletic process. For this purpose, they created an observational survey known as Integrated System of Training Task Analysis (SIATE). This survey records six variables: degree of opposition, density of task, percentage of simultaneous participants, competitive load, space of play and cognitive involvement. The variables are scored from 1 (minimum load) to 5 (maximum load). The sum of the scores provides a measurement of the total load of the task.

Coque (2009) suggests a tool that, similarly to the previous one, aims to evaluate the training load using a direct observation. The analysis system is the Subjective Evaluation of the technicaltactical training load (VSC), in which six variables are recorded: degree of obstacle, density of the task, percentage of simultaneous executions, competitive load, field of play and cognitive involvement. The variables are scored from 1 (minimum load) to 4 (maximum load). The sum of the scores provides a measurement of the total load of the task.

Both of them can be used to calculate the total load of the task, which would be the total of the assessed values, and the load weighted for the length of the task, which would be calculated by

PeerJ reviewing PDF | (2021:05:60847:1:1:NEW 13 Jul 2021) 
277 multiplying the total load by the useful time of the task in minutes. The latter shows more precision 278 in the real load of the task. Reina et al. (2019) shows that the SIATE organic system gives us the 279 same information as that recorded by inertial devices or HR monitors. Also, Valles et al. (2017) 280 show that VSC has a strong correlation with RPE. Studies that analyze correlations between 281 individual variables to see the percentage of the variability as a function of the cognitive load have 282 not been found.

283 Measurement Period: After the session/competition

284

285

286

287

288

289

290

291

292

293

294

295

296

297

298

299

300

301

302

303

304

305

306

307

308

309

310

311

\section{Physiological Indicators}

\section{Heart Rate Variability (HRV)}

Heart Rate Variability is defined as the temporal variation of the heart rate during a specified time period (Capdevila y Niñerola, 2006). In the simplest way, HRV has been analysed within the time domain, but more complex evaluations include an analysis within the frequency domain and nonlinear methods (García Manso, 2013).

The Autonomic Nervous System (ANS) is responsible for the regulation of the HRV through parasympathetic and sympathetic modulation (Bricout et al., 2010), the balance of which is disrupted after changes in the training load (Pichot et al., 2002). This is the reason why many studies define HRV analysis as a useful, non-invasive method to evaluate the function of the ANS (Bellenger et al., 2016; Bosquet et al, 2008; Hynynen et al., 2006; Parrado et al., 2010). The findings in the Thayer et al. (2009) study suggest an important relationship between cognitive performance and HRV, reaffirming the relevance of this information to measure the effect of cognitive load.

Even though the literature in control situations suggests that HRV is very sensitive to demands on the cognitive load (Luque-Casado et al., 2016), no significant differences have been found in HRV comparing HRV control situations and mental overload (Gantois et al., 2019).

Measurement period: Before the session

\section{Behavioral Indicators}

\section{Reaction time or response time}

Reaction time is calculated as the time from the beginning of the stimulus until the corresponding response of the participant (Gabbett y Benton, 2009). This indicator depends mainly on, but may be affected by age, gender or duration of the stimulus (Der and Deary, 2006), on cognitive processes, which means that mental fatigue could be inhibitory (Huijgen et al., 2015) and could increase the response time. It should be noted, however, that beyond a certain duration and/or 313 intensity of exercise, muscle fatigue induces an increase in reaction time which may be due to a

314 decrease in cognitive performance. fatigue induces an increase in reaction time that may be due to 315 a decrease in cognitive performance (Chmura et al., 1994).

316 
317 In Scanlan et al. (2013) response time is identified as the only variable that predicts the time of 318 reactive agility in the phased model. This serves us to determine the influence of physical and 319 cognitive factors on the development of reactive agility in basketball players. Gantois et al.

320 (2019) found a significant increase in reaction time in relation to increased mental fatigue

321 induced by the Stroop task. This increased reaction time impairs the decision making of soccer

322 players and thus their performance. Coinciding with these results, Moreria et al. (2018) saw an

323 increase in reaction time caused by mental fatigue in a Stroop task. Reaction time underwent a

324 significant decrease during the test, except for the last five minutes in which it was maintained

325

326

Measurement period: During a task previous to training/competition

327

328

\section{Decision-making time}

329

Making a successful decision depends on the ability of the player to identify, select and then

330 execute the correct action in response to the postural signs of opponents or teammates, recognizing significant patterns in the game and determining the situational probabilities (Roca et al., 2013; Williams et al., 2011). Decision-making time is determined as the time interval between the first identifiable contact of the stimulus-player and the first identifiable contact that initiates the participant's response (Gabbett y Benton, 2009). This cognitive ability to make fast and precise decisions is fundamental for success in football (Smith et al., 2016), an observation that can be applied to the rest of the team sports.

337

338

339

340

341

342

343

344

345

\section{Conclusions}

347

348

349

350

351

352

353

354

355

In Scanlan et al. (2013) decision-making time is identified as a variable which is highly associated with agility time. This cognitive measurement, together with reaction time, was the one that influenced the basketball players the most. Gantois et al. (2019) showed that induced mental fatigue damaged the decision-making process, provoking a decrease in performance. These findings agree with those of Smith et al. (2016), determining that mental fatigue affected the decision-making precision and time of the football players.

Measurement period: During the task

\section{Relation with internal and external load}

Cognitive factors interact with physiological and mechanical factors which are present during training and competition. For this reason, distinguishing their connections can be a significant element in the research of load management in sport (Soligard et al., 2016). In this context, the loads that the athletes assume involve stress and provoke changes in their physical and psychological well-being. Furthermore, understanding the interaction between these loads, perceptive well-being and readiness for training or competition will provide us with significant individual training prescriptions (Gabbett et al., 2017). 
356 The IL measured through RPE is significantly connected to variations in cognitive load imposed 357 by the training exercises, as evaluated by cognitive indicators such as the NASA-TLX 358 questionnaire (Camacho et al., 2020) or the VAS MF scale (Badin et al., 2016; Sansone et al., 359 2020; Veness et al., 2017). This increase in cognitive fatigue has a direct impact on the internal 360 load, provoking a modulation of the endocrine response attenuating the concentration of 361 testosterone and alpha-amylase, markers of the activity of the mesolimbic pathways and the 362 sympathetic nervous system, respectively (Moreira et al., 2018). There were no studies showing 363 significant correlations between the internal load taken from the HR and the cognitive load taken 364 from the NASA-TLX questionnaire (Badin et al., 2016), except for the study conducted by Farrow

365

366

367

368

369

370

371

372

373

374

375

376

377

378

379

380

381

382

383

384

385

386

387

388

389

390

391

392

393

394

et al. (2008) which showed increases in the RPE-Cog and the HR during open exercises.

Moreover, the EL recorded through tracking systems shows that players under high cognitive load conditions (VAS MF) register higher values for total distance, average speed and run time at a moderate speed, demonstrating higher intensity efforts (Coutinho et al., 2017; Kunrath et al., 2020). This condition of mental fatigue damages aspects of the tactical behavior of the players, causing a compensatory increase in the physical performance (Kunrath et al., 2020). Position variables, taken from GPS analysis, are also affected in high cognitive load conditions, provoking a decrease of the longitudinal synchronization (coordination of longitudinal movements of the players during the game), of the stretch index (represented by the average distances of each player from the geometric gravity centers of the team) and of the distance between dyads (distance between a pair of players that share the same environment and intend to reach the same team objective) (Coutinho et al., 2018). This deterioration of physical performance (physical variables) and elapsed synchronization time (position variables) should alert us that cognitive load should be considered a variable that can be controlled with the objective of improving collective behavior.

The models of training load control that take into account cognitive load such as the CSE or VSC can offer the same information as more difficult methods (Reina et al., 2019; Vallés et al., 2017). However, we must take into account that they are both subjective recording systems.

\section{Practical applications}

To optimize performance and exert more control over training processes and/or competition in team sports, it is necessary to have load control strategies which include cognitive load in the monitoring cycles of the athlete. However, there is limited literature related to this concept.

NASA-TLX, VAS MF or Cognitive-RPE analysis strategies are considered valid to measure the impact of the cognitive load in team sports. Other control methods like VFC, reaction time or decision-making time need scientific evidence. In this sense, there is a clear lack of studies which use objective tools to measure the cognitive load. 
395

396

397

398

399

400

401

402

403

404

405

406

407

408

409

410

411

412

413

414

415

416

417

418

419

420

421

422

423

424

425

426

427

428

429

430

431

432

433

434

The evaluation of external, internal and cognitive demands in an isolated way would be potentially problematic, because we would only obtain information on the provided stimulus, the processed stimulus or the players responses without examining the inherent connections. Even though it is accepted that external, internal and cognitive demands are separate constructs, they must be analyzed and interpreted in the same context, and they must be considered as a whole in order to optimize performance and prevent injuries. Processing systems will produce an alteration in the stimulus that generates physiological responses, so the manipulation of one of these three constructs will provoke changes in the others. With this objective, future studies that delve into this paradigm will be justified.

\section{References}

Alarcón, F., Castillo-Díaz, A., Madinabeitia, I., Castillo-Rodríguez, A., and Cárdenas, D. (2018). La carga mental deteriora la precisión del pase en jugadores de fútbol. J Sport Psychol, 27(2), 155164.

Alarcón, F., Ureña, N., and Cárdenas, D. (2017). La fatiga mental deteriora el rendimiento en el tiro libre en baloncesto. Rev Psicol Deporte, 26(1), 33-36.

Arruda, A., Aoki, M., Paludo, A., and Moreira, A. (2017). Salivary steroid response and competitive anziety in elite basketball players: Effect of opponent level. Physiol Behav, 177, 291296.

Badin, O., Smith, M., Conte, D., and Coutts, A. (2016). Mental fatigue impairs technical performance in small-sided soccer games. Int J Sport Physiol, 11(8), 1100-1105.

Barrett, S., McLaren, S., Spears, I., Ward, P., and Weston, M. (2018). The influence of playing position and contextual factors on soccer players' match differential ratings of perceived exertion: a preliminary investigation. Sports, 6, 13 .

Bellenger, C., Fuller, J., Thomson, R., Davison, K., Robertson, E., and Buckley, J. (2016). Monitoring athletic training status through autonomic heart rate regulation: a systematic review and meta-analysis. Sports Med, 46, 1461 - 1486.

Ben Abdelkrim, N., El Fazaa, S., El Ati, J., and Tabka, Z. (2007). Time-motion analysis and physiological data of elite under-19-year-old basketball players during competition. Brit J Sports Med, 41, 69-75.

Bosquet, L., Merkari, S., and Arvisais, D. (2008). Is heart rate a conve- nient tool to monitor overreaching? A systematic review of the literature. Brit J Sports Med, 42, 709-14. 
435 Borg, G., and Borg, E. (2001) A new generation of scaling methods: Level-anchored ratio scaling. 436 Psychologica, 28(1), 15-45.

437

438

439

440

441

442

443

444

445

446

447

448

449

450

451

452

453

454

455

456

457

458

459

460

461

462

463

464

465

466

467

468

469

470

471

472 Coutinho, D., Gonçalves, B., Travassos, B., Wong, D., Coutts, A., and Sampaio, J. E. (2017).

473 Mental fatigue and spatial references impair soccer players' physical and tactical performances.

474 Front Psychol, 8, 1645.

Borg, G., P. Hassmen., and M. Langerstorm (1985). Perceived exertion in relation to heart rate and blood lactate during arm and leg exercise. Eur J Appl Physiol, 65: 679-685.

Bricout, V., DeChenaud, S., and Favre, A. (2010). Analyses of heart rate variability in young soccer players: The effects of sport activity. Auton Neurosci, 154, 112-116.

Brown, D.M.Y., Graham, J.D., Innes, K.I. (2020). Effects of Prior Cognitive Exertion on Physical Performance: A Systematic Review and Meta-analysis. Sports Med, 50, 497-529.

Camacho, P., Cruz, D., Madinabeitia, I., Giménez, F., and Cárdenas, D. (2020). Time constraint increases mental load and influences in the performance in small-sided games in basketball. Res Q Exercise Sport.

Capdevila, L. (2001). Metodología de evaluación en psicología del deporte. En J. Cruz (Ed.). Rev Psicol Deporte, 111-146.

Capdevila, L., and Niñerola, J. (2006). Evaluación psicológica en deportistas. En E. Garcés (Ed), Deporte y Psicología, 145-176.

Cárdenas, D., Perales, J., Chirosa, L., Conde-González, J., Aguilar, D., and Araya, S. (2013). The effect of mental workload on the intensity and emotional dynamics of perceived exertion. $A n$ Psicol, 29(3), 662-673.

Cárdenas, D., Conde-González, J., and Perales, J. (2015). El papel de la carga mental en la planificación del entrenamiento deportivo. Rev Psicol Deporte, 24(1), 91-100.

Chmura, J., Nazar, K., and Kaciuba-Uscilko, H. (1994) Choice reaction time during graded exercise in relation to blood lactate and plasma catecholamines thresholds. Int J Sports Med, 15(4), $172-176$.

Coutinho, D., Gonçalves, B., Travassos, B., Coutts, A., Wong, D., and Sampaio, J. E. (2018). Exploring the effects of mental and muscular fatigue in soccer players' performance. Hum Movement Sci, 58, 287-296. 
475

476

477

478

479

480

481

482

483

484

485

486

487

488

489

490

491

492

493

494

495

496

497

498

499

500

501

502

503

504

505

506

507

508

509

510

511

512

513

Der G., and Deary I. J. (2006). Age and sex differences in reaction time in adulthood: results from the United Kingdom health and lifestyle survey. Psychol Aging, 21(1), 62.

Fanchini, M., Ferraresi, I., Modena, R., Schena, F., Coutts, A.J., and Impellizzeri, F.M. (2016). Use of CR100 scale for session-RPE in soccer and interchangeability with CR10. Int J Sport Physiol, 11(3), 388-392.

Farrow, D., Pyne, D., and Gabbett, T. (2008). Skill and physiological demands of open and closed training drills in australian football. Int J Sports Sci Coach, 3(4), 489-499.

Figueira, B., Exel, J., Gonçalves, B., Masiulis, N., and Sampaio, J. (2019). Exploring new approaches to access cognitive demands in football small-sided games. Motricidade, 15(160), 183-184.

Foster, C., Florhaug, JA., Franklin, J., et al. (2001). A new approach to monitoring exercise training. J Strength Cond Res, 15(1), 109-115.

Gabbett, T., Jenkins, D., and Abernethy, B. (2010). Physiological and skill demands of on-side and off-side games. J Strength Cond Res, 24 (11), 2979-2983.

Gabbett, T., Kelly, J., and Sheppard, J. (2009). Speed, change of direction speed, and reactive agility of rugby league players. J Strength Cond Res, 22(1), 174-181.

Gabbett, T., Nassis, P., Oetter, E., Pretorius, J., Johnston, N., Medina, D., Rodas, G., Myslinski, T., Howells, D., Beard, A., and Ryan, A. (2017). The athlete monitoring cycle: a practical guide to interpreting and applying training monitoring data. Brit J Sports Med, $0,0$.

Gantois, P., Caputo Ferreira, M., Lima-Junior, D., Nakamura, F., Batista, R., Fonseca, F., and de Sousa, L. (2019). Effects of mental fatigue on passing decision-making performance in professional soccer athletes. Eur J Sport Sci,20 (4), 534-543.

García-Calvo, T., González-Ponce, I., Ponce, J., Tomé-Lourido, D., and Vales-Vázquez, A. (2019). Incidencia del sistema de puntuación de las tareas sobre la carga mental del entrenamiento en fútbol. J Sport Psychol, 28(2), 79-86.

García Manso, JM. (2013). Aplicación de la variabilidad de la frecuencia cardiaca al control del entrenamiento deportivo: análisis en modo frecuencia. Arch Med Deporte, 30(1), 45-51.

PeerJ reviewing PDF | (2021:05:60847:1:1:NEW 13 Jul 2021) 
514 Gil-Rey, E., Lezaun, A. and Los Arcos, A. (2015) Quantification of the perceived training load 515 and its relationship with changes in physical fitness performance in junior soccer players. J Sport 516 Sci, 33(20), 2125-2132.

517

518 Gonçalves, B., Marcelino, R., Torres-Ronda, L., Torrents, C., and Sampaio, J. (2016). Effects of 519 emphasising opposition and cooperation on collective movement behaviour during football small520 sided games. J Sport Sci, 34(14), 1346-1354.

521

522 Goodger, K., Gorely, T., Lavallee, D., and Harwood, C. (2007). Burnout in sport: A systematic

523

524

525

526

527

528

529

530

531

532

533

534

535

536

537

538

539

540

541

542

543

544

545

546

547

548

549

550

551

552

553

554

review. Sport Psychol, 21(2), 127-151.

Gould, D., Kelly, D., Goldstone, L., and Gammon, J. (2001). Examining the validity of pressure ulcer risk assessment scales: developing and using illustrated patient simulations to collect the data. J Clin Nurs, 10, 697-706.

Kunrath, C., Nakamura, F., Roca, A., Tessitore, A., and Da Costa, I. (2020). How does mental fatigue affect soccer performance during small-sided games? A cognitive, tactical and physical approach. J Sport Sci, 38(15), 1818-1828.

Hynynen, E., Uusitalo, A., Konttinen, N. and Rusko. (2006). Heart rate variability during night sleep and after awakening in overtrained athletes. Med Sci Sports Exerc, 38, 313-317.

Huijgen, B., Leemhuis, S., Kok, N., Verburgh, L., Oosterlaan, J., Elferink-Gemser, M., and Visscher, C. (2015). Cognitive functions in elite and sub-elite youth soccer players aged 13 to 17 years. PLoS ONE, 10(12), 1-13.

Job, R., and Dalziel, J. (2001). Defining fatigue as a condition of the organism and distinguishing it from habituation, adaptation, and boredom. In P. A. Hancock \& P. A. Desmond (Eds.), Stress, workload, and fatigue, 466-475.

Lee, K. A., Hicks, G., and Nino-Murcia, G. (1991). Validity and reliability of a scale to assess fatigue. Psychiat Res, 36, 291-298.

Lin, S., Hsiao, Y., and Wang, M. (2014). Test Review: The profile of mood states. J Psychoeduc Assess, 32, 273.

Lord, F., Pyne, D., Welvaert, M., and Mara, J. (2020). Methods of performance analysis in team invasion sports: A systematic review. J Sport Sci, 1-12.

Luque-Casado, A., Perales, J., Cardenas, D., and Sanabria, D. (2016). Heart rate variability and cognitive processing: The autonomic response to task demands. Biol Psychol, 113, 83 - 90.

Peer] reviewing PDF | (2021:05:60847:1:1:NEW 13 Jul 2021) 
555

556

557

558

559

560

561

562

563

564

565

566

567

568

569

570

571

572

573

574

575

576

577

578

579

580

581

582

583

584

585

586

587

588

589

590

591

592

593

Mashiko, T., Umeda, T., Nakaji, S., and Sugawara, K. (2004). Position related analysis of the appearance of and relationship between post-match physical and mental fatigue in university rugby football players. Brit J Sports Med, 34, 617-621.

Marcora, S., Staiano, W., and Manning, V. (2009). Mental fatigue impairs physical performance in humans. J Appl Physiol, 106(3), 857-864.

Martens, R., Burton, D., Vealey, R. S., Bump, L. A., and Smith, D. (1990). Development and validation of the Competitive State Anxiety Intentory-2. Champaing, Illinois: Human Kinetics, 127-140.

McLaren, S., Smith, A., Spears, I., and Weston, M. (2016). A detailed quantification of differential ratings of perceived exertion during team-sport training. J Sci Med Sport, 20 (3), 290-295.

McNair, DM., Losr M, and Droppleman, LF. (1971). Profile of mood states manual. San Diego, CA: Educational and Industrial Testing Service.

Moreira, A., Aoki, M., Franchini, E., Machado, D., Paludo, A., and Okano, A. (2018). Mental fatigue impairs technical performance and alters neuroendocrine and autonomic responses in elite young basketball players. Physiol Behav, 196, 112-118.

Mujika, I., Halson, S., Burke, L., Balagué, G., and Farrow, D. (2018). An Integrated, Multifactorial Approach to Periodization for Optimal Performance in Individual and Team Sports. Int J Sport Physiol, 2018, 13, 538-561.

Parrado, E., Garcia, M. A., Ramos, J., Cervantes, J., Rodas, G. y Capdevila, L. (2010). Comparision of two devices to detect RR intervals. Int J Sport Med, 31, 336-341.

Paulauskas, H., Kreivyte, R., Scanlan, A.T., Moreira, A., Siupsinskas, L., and Conte, D. (2019). Monitoring Workload in Elite Female Basketball Players During the In-Season Phase: Weekly Fluctuations and Effect of Playing Time. Int J Sport Physiol, 14 (7), 941-948.

Pichot, V., Busso, T., and Roche, F. (2002). Autonomic adaptations to intensive and overload training periods: a laboratory study. Med Sci Sports Exerc, 34 (10), 1660-6.

Raglin, JS., Morgan, WP., and O'Connor, PJ. (1991). Changes in mood states during training in female and male college swimmers. Int J Sports Med, 12, 585-9.

PeerJ reviewing PDF | (2021:05:60847:1:1:NEW 13 Jul 2021) 
594 Reina, M., Mancha-Triguero, D., García-Santos, D., García-Rubio, D., and Ibáñez, S. (2019). 595 Comparación de tres métodos de cuantificación de la carga de entrenamiento en baloncesto. Rev 596 Int Cienc Deporte, 15, 368-382.

597

598

599

600

601

602

603

604

605

606

607

608

609

610

611

612

613

614

615

616

617

618

619

620

621

622

623

624

625

626

627

628

629

630

631

632

633

634

Roca, A., Ford, P., McRobert, A., and Williams, A. (2013). Perceptual-cognitive skills and their interaction as a function of task constraints in soccer. J Sport Exerc Psychol, 35(2), 144-155.

Rottenberg, J., and Gross, J. J. (2003). When emotion goes wrong: Realizing the promise of affective science. Clin Psychol Rev: Science and Practice, 10(2), 227-232.

Sansone, P., Tessitore, A., Lukonaitiene, I., Pauklauskas, H., Tschan, H., and Conte, D. (2020). Technical-tactical profile, perceived exertion, mental demands and enjoyment of different tactical tasks and training regimes in basketball small-sided games. Biol Sport, 37(1), 15-23.

Scanlan, A., Humphries, B., Tucker, P., and Dalbo, V. (2013). The influence of physical and cognitive factors on reactive agility performance in men basketball players. J Sport Sci, 32, 36774.

Schelling, X., and Torres-Ronda, L. (2013). Conditioning for basketball: Quality and quantity of training. J Strength Cond Res, 35, 89-94.

Schmeichel, B.J. (2007). Attention control, memory updating, and emotion regulation temporarily reduce the capacity for executive control. J. Exp. Psychol. 136(2), 241.

Smith, M., Coutts, A., Merlini, M., Deprez, D., Lenoir, M., and Marcora, S. (2016). Mental fatigue impairs soccer-specific physical and technical performance. Med Sci Sports Exerc, 48(2), 267276.

Smith, M., Zeuwts, L., Lenoir, M., Hens, N., De Jong, L., and Coutts, A. (2016). Mental fatigue impairs soccer-specific decision-making skill. J Sport Sci, 34(14), 1297-304.

Soligard, T., Schwellnus, M., Alonso, J.M., Bahr, R., Clarsen, B., Dijkstra, P., Gabbett, T., Gleeson, M., Hägglund, M., Hutchinson, M., Rensburg, C., Khan, K., Meeusen, R., Orchard, J., Pluim, B., Raftery, M., Budgett, R., and Engebretsen, L. (2016). How much is too much) (Part 1) International Olympic Committee consensus statement on load in sport and risk of injury. Brit J Sports Med, 50, 1030-1041.

Stewart, LA., Clarke, M., Rovers, M., Riley, R., Simmonds, M., Steward, G., and Tierney, J (2015) Preferred reporting items for systematic review and meta-analyses of individual participant data: the PRISMA-IPD statement. Jama, 313: 1657-1665.

Peer) reviewing PDF | (2021:05:60847:1:1:NEW 13 Jul 2021) 
635 Taylor, J., Wright, A., Dischiavi S., Townsend M., and Marmon A. (2017) Activity Demands 636 During Multi-Directional Team Sports: A Systematic Review. Sports Med, 47(12), 2533-2551.

637

638 Thayer, J., Hansen, A., Saus-Rose, E., and Johnsen, B. (2009). Heart rate variability, prefrontal 639 neural function, and cognitive performance: the neurovisceral integration perspective on self640 regulation, adaptation, and health. Ann Behav Med, 37(2), 141-153.

641

642 Vallés, C., Fernández-Ozcorta, E., and Suero, F. (2017). Relación entre la complejidad técnico643 táctica en la sesión de entrenamiento y la carga interna en baloncesto femenino. Rev Euroamer 644 Cienc Deporte, 6(1), 163-168.

645

646 Van Cutsem, J., Marcora, S., De Pauw, K. (2017). The Effects of Mental Fatigue on Physical 647 Performance: A Systematic Review. Sports Med, 47, 1569-1588.

648

649 Vaughan, R., Laborde, S., and McConville, C. (2018). The effect of athletic expertise and trait 650 emotional intelligence on decision-making. Eur J Sport Sci., 1-9.

651

652 Veness, D., Patterson, S., Jeffries, O., and Waldron, M. (2017). The effects of mental fatigue on 653 cricket-relevant performance among elite players. J Sport Sci, 35(24), 2461-2467.

654

655 Williams, A., Ford, P., Eccles, D., and Ward, P. (2011) Perceptual- cognitive expertise in sport 656 and its acquisition: Implications for applied cognitive psychology. Appl Cog Psychol, 25(3), 432657442. 
Figure 1

Flowchart 

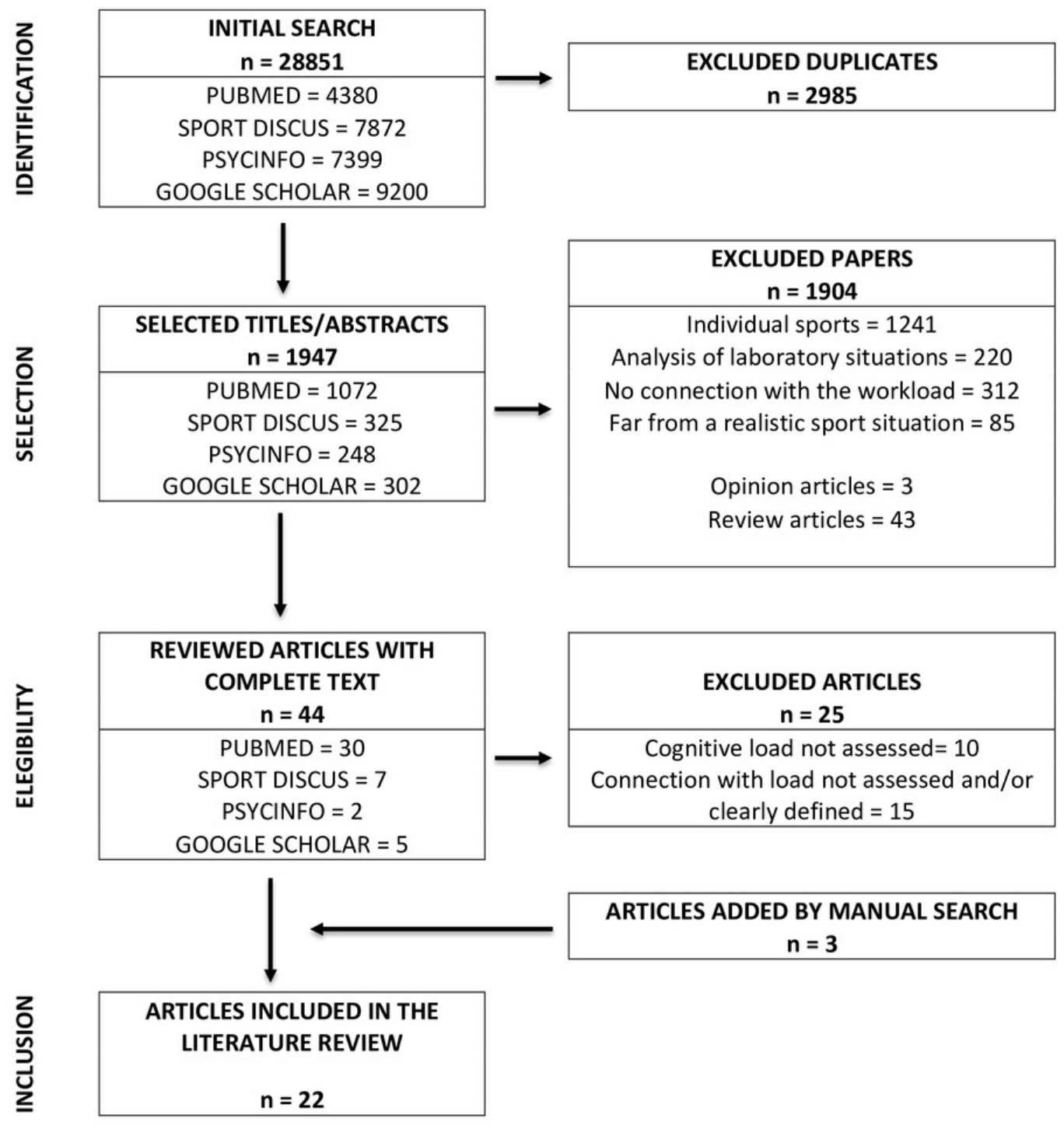


\section{Table 1 (on next page)}

Managing of cognitive load with cognitive indicators 
1

\begin{tabular}{|c|c|c|c|c|c|c|c|c|c|c|}
\hline Author & Year & n. & Objective & Task & $\begin{array}{c}\text { Cognitive } \\
\text { Load } \\
\text { Variables }\end{array}$ & $\begin{array}{c}\text { Internal } \\
\text { Load } \\
\text { Variables }\end{array}$ & $\begin{array}{l}\text { External Load } \\
\text { Variables }\end{array}$ & $\begin{array}{l}\text { Measurement } \\
\text { Period }\end{array}$ & Results & Conclusion \\
\hline $\begin{array}{l}\text { Camacho } \\
\text {, et al. }\end{array}$ & 2020 & $\begin{array}{c}22 \\
\text { university } \\
\text { students } \\
\text { with less } \\
\text { than two } \\
\text { years of } \\
\text { experience } \\
\text { playing } \\
\text { basketball } \\
(20,81 \pm \\
1,76)\end{array}$ & $\begin{array}{l}\text { To explore the } \\
\text { impact of four } \\
\text { task restrictions } \\
\text { on mental load } \\
\text { and their } \\
\text { consequences } \\
\text { for individual } \\
\text { and team } \\
\text { performance in } \\
\text { small-sided } \\
\text { basketball } \\
\text { games (SSG). }\end{array}$ & $\begin{array}{l}4 \text { sessions of } 3 \times 3 \\
\text { SSG using the full } \\
\text { court }\left(5 \times 22^{\prime}, 2^{\prime} \text { rec.) }\right. \\
\text { with restrictions: } \\
\text { A) Normal game } \\
\text { B) Temporal } \\
\text { restriction (7" to } \\
\text { score) } \\
\text { C) Restriction of } \\
\text { passes per } \\
\text { possession } \\
\text { D) Conditions } 2 \text { and } \\
3 \text { simultaneously }\end{array}$ & $\begin{array}{l}\text { Mental load } \\
\text { (NASA- } \\
\text { TLX, a.u.), } \\
\text { affective } \\
\text { response } \\
\text { (PANAS } \\
\text { questionnai } \\
\text { re, a.u.) }\end{array}$ & $\begin{array}{l}\text { Rating of } \\
\text { perceived } \\
\text { exertion } \\
\text { (RPE) Borg } \\
\text { scale 6-20 } \\
\text { a.u., \%HR } \\
\text { peak, } \\
\text { Edwards' } \\
\text { Heart rate } \\
\text { zones }\end{array}$ & $\begin{array}{l}\text { Ratio of } \\
\text { successful } \\
\text { offensive } \\
\text { possessions (total } \\
\text { num. of made } \\
\text { shots / total num. } \\
\text { of offensive } \\
\text { possessions), ratio } \\
\text { of successful } \\
\text { passes (successful } \\
\text { passes / total num. } \\
\text { of passes), ratio of } \\
\text { rebounds (num. of } \\
\text { captured rebounds } \\
\text { / num. of off and } \\
\text { def missed shots) }\end{array}$ & $\begin{array}{l}\text { During the task: } \\
\text { \%HR peak, } \\
\text { Edwards HRZ, } \\
\text { CE Variables } \\
\text { After the task: } \\
\text { NASA-TLX, } \\
\text { PANAS, RPE }\end{array}$ & $\begin{array}{l}\text { Statistical analysis } \\
\text { showed that restrictions } \\
\text { B, C, and D produced } \\
\text { more mental load, } \\
\text { provoking differences } \\
\text { both in affective } \\
\text { response and RPE, and } \\
\text { consequently impairing } \\
\text { performance. } \\
\text { No significant } \\
\text { differences were found } \\
\text { in regards to the Internal } \\
\text { Load of the sessions, } \\
\text { extracted from the HR. }\end{array}$ & $\begin{array}{l}\text { Restrictions imposed on } \\
\text { SSG had a significant } \\
\text { impact on subjective } \\
\text { perceptions and } \\
\text { cognitive and emotional } \\
\text { responses. The analyzed } \\
\text { restrictions are seen as } \\
\text { an efficient way to } \\
\text { increase the decision- } \\
\text { making difficulty and, } \\
\text { consequently, the mental } \\
\text { load. It is valid to } \\
\text { consider the collective } \\
\text { performance, rather than } \\
\text { the individual, as a way } \\
\text { to generate a greater } \\
\text { mental load }\end{array}$ \\
\hline $\begin{array}{l}\text { Kunrath, } \\
\text { et al. }\end{array}$ & 2020 & $\begin{array}{l}18 \text { amateur } \\
\text { football } \\
\text { players } \\
(21,8 \pm 2,5)\end{array}$ & $\begin{array}{l}\text { To examine } \\
\text { how mental } \\
\text { fatigue (MF) } \\
\text { has an influence } \\
\text { on peripheral } \\
\text { perception, } \\
\text { tactical } \\
\text { behavior and } \\
\text { physical } \\
\text { performance } \\
\text { during a SSG in } \\
\text { football }\end{array}$ & $\begin{array}{l}\text { Two sessions were } \\
\text { carried out: } \\
\text { Control: Control } \\
\text { visualization } \\
\text { followed by SSG } \\
\text { test task } \\
\text { "Goalkeeper + 3vs3 } \\
\text { + Goalkeeper" } \\
\text { MF condition: } \\
\text { Stroop task followed } \\
\text { by SSG test task } \\
\text { "Goalkeeper + 3vs3 } \\
\text { + Goalkeeper" }\end{array}$ & $\begin{array}{l}\text { Mental } \\
\text { fatigue } \\
\text { (MF) 100- } \\
\text { mm VAS } \\
\text { a.u. }\end{array}$ & $\begin{array}{l}\text { Peripheral } \\
\text { perception } \\
\left({ }^{\circ}\right)\end{array}$ & $\begin{array}{l}\text { System of Tactical } \\
\text { Assessment in } \\
\text { Football (FUT- } \\
\text { SAT), Tracking } \\
\text { systems: Intensity } \\
\text { zones in the } \\
\text { distance covered, } \\
\text { total distance } \\
\text { covered, average } \\
\text { V and max. V }\end{array}$ & $\begin{array}{l}\text { Before and after } \\
\text { the Stroop task: } \\
\text { VAS MF, } \\
\text { peripheral } \\
\text { perception } \\
\text { During the } \\
\text { SSG: FUT-SAT } \\
\text { and tracking } \\
\text { system } \\
\text { variables }\end{array}$ & $\begin{array}{l}\text { MF diminished } \\
\text { peripheral perception. } \\
\text { Also, it induced a } \\
\text { reduction in precision of } \\
\text { tactical actions: } \\
\text { offensive coverage, } \\
\text { offensive unity, balance, } \\
\text { concentration, mobility, } \\
\text { and defensive depth and } \\
\text { unity. Under MF } \\
\text { conditions, players had } \\
\text { elevated values for total } \\
\text { distance, average V and } \\
\text { time running at a } \\
\text { moderate velocity. } \\
\text { Greater high-intensity } \\
\text { efforts were observed. }\end{array}$ & $\begin{array}{l}\text { MF decreases peripheral } \\
\text { perception provoking } \\
\text { more errors for most } \\
\text { tactical actions. The MF } \\
\text { condition damages the } \\
\text { cognitive and tactical } \\
\text { aspects of the players' } \\
\text { behavior, causing a } \\
\text { compensatory increase in } \\
\text { the physical } \\
\text { performance. }\end{array}$ \\
\hline
\end{tabular}




\begin{tabular}{|c|c|c|c|}
\hline $\begin{array}{l}\text { Sansone, } \\
\text { et al. }\end{array}$ & 2020 & $\begin{array}{c}12 \text { semi- } \\
\text { professiona } \\
1 \text { basketball } \\
\text { players } \\
(21 \pm 2 \\
\text { years) }\end{array}$ & $\begin{array}{l}\text { To assess the } \\
\text { technical- } \\
\text { tactical, } \\
\text { perceptive and } \\
\text { mental demands } \\
\text { of SSG in } \\
\text { basketball. }\end{array}$ \\
\hline
\end{tabular}

To examine the

SSG sessions:

Mental

Short attack

(6×2', 1' rec.)

) Long defens

(3x4', 2' rec.)

4) Short defense

$(6 \times 2$ ', 1' rec.)

4 drills (12'):

1) $\mathrm{SSG}$, reduced

(MF) 100-

mm VAS

a.u., Menta

RPE with

centiMax

scale a.u.,

exertion enjoyment

(ME) 100- 100-mm

mm VAS

a.u.
García-

Calvo,

$$
\text { al. }
$$

2019

profession

1 soccer

$(17,32 \pm$

1,21 years) effect of

modifying the

on the cognitive

oad perceive

by football

players due to

training tasks

game $5 \mathrm{v} 5$

2) SSG 5vs5 with

psycho-tactical load

(scoring system)

3) Possession $5 v s 5$

4) Possession with

Mental load

(adapted

NASA -

VAS

avg, HR

$\max$.

psycho-tactical load fatigue a.u.

(scoring system)

Externa

To quantify the training load via

Adult

amateur

three types of

$\begin{gathered}\text { Reina, et } \\ \text { al. }\end{gathered}$
$2019 \quad \begin{gathered}\text { female } \\ \text { basketball } \\ \text { team }(>18\end{gathered}$

team $(>18$

establish

possible

relationships

between the

measurements

utilized subjective

load test

items

Different training

tasks were analyzed

(a total of 120 tasks)

(STATE): competitive

load and

cognitive

$\mathrm{t}$

(scale from

0 - 5) a.u.
$\%$
Offensive tasks require

greater ME in

Right before the comparison with

task: VAS MF

defensive ones.

Short SSG induce better

$\begin{array}{ll}\text { During the task: } & \text { RPE and ME responses, } \\ \text { T-T video } & \text { as well as an increase in }\end{array}$

as well as an increase in

the demands of the game

ideo analysis

5 ' after the task:

and shots)

RPE, VAS MF,

VAS ME, VAS

associated with

Enjoyment

variations of menta

fatigue provoked by the training exercises.

The experimental task involves a significant increase of the load and

During the task: the mental fatigue, in

HR, HR max, respect with the control

Sprints, V avg task; having more impact

$\mathrm{N}^{\mathrm{o}}$ sprints, $\mathrm{V}$ avg At the end of on the SSG than in the

possession drills. The

NASA-TLX, $\quad \begin{aligned} & \text { possession drills. The } \\ & \text { physical load and the }\end{aligned}$

VAS MF

mental load behave in a

different way: control

30' later: RPE

situations, greater PL;

experimental situations,

greater ML.

SIATE (Integrate

System of

Training Task

Analysis)

(Opposition

Maximum degree, task were measured

play and

percentage of

performers),

Player load
All averages

The subjective load

measurement maintains

statistically significan

correlation with the

variables of objective

during training

$\%$ MHR. The

SIATE task is a reliable

method of analysis to

track the load of the

players.
The short SSG induced a

greater volume of

offensive play and

different tech-tac

haviors, (number of

possessions and

ndividual or collective

actions). The offensive

task is more demanding

than the individual one,

in terms of perceived

effort and mental effort

The modified scoring system significantly

affected the mental load and mental fatigue, with a stronger effect on the SSG than the possession drill. The physical and mental load behaved differently.

The use of the SIATE ecological system to register tasks gives us the same information as ther more expensive formation systems, such as inertial devices or HR bands. 


\begin{tabular}{|c|c|c|c|c|c|c|}
\hline $\begin{array}{l}\text { Alarcón, } \\
\text { et al. }\end{array}$ & 2018 & $\begin{array}{c}28 \\
\text { semiprofess } \\
\text { ional } \\
\text { football } \\
\text { players } \\
\text { ( } 20,07 \pm \\
0,23 \text { years) }\end{array}$ & $\begin{array}{l}\text { To advance the } \\
\text { study of the } \\
\text { relationship } \\
\text { between mental } \\
\text { and physical } \\
\text { load during } \\
\text { athletic } \\
\text { activities and } \\
\text { see how this } \\
\text { interaction } \\
\text { influences } \\
\text { athletic } \\
\text { performance. }\end{array}$ & $\begin{array}{l}\text { A football-specific } \\
\text { task with acoustic } \\
\text { signals that } \\
\text { alternates sprints of } \\
12 \mathrm{~m} \text {, jogging } \\
\text { displacements and } \\
\text { passes. Objectives } \\
\text { of passing precision. } \\
\text { Counterbalanced } \\
\text { design between two } \\
\text { conditions: without } \\
\text { mental load (AML) } \\
\text { and with mental } \\
\text { load (ML) } 2 \times\left(3 \times 3^{\prime}-\right.\end{array}$ & $\begin{array}{l}\text { Mental load } \\
\text { (adapted } \\
\text { NASA - } \\
\text { TLX, a.u.), } \\
\text { Emotional } \\
\text { state ( Self- } \\
\text { assessment } \\
\text { manikin } \\
\text { scale, } \\
\text { SAM, a.u.) }\end{array}$ & $\begin{array}{l}\text { Anxiety } \\
\text { level (STAI } \\
\text { questionnai } \\
\text { re, a.u.) }\end{array}$ \\
\hline $\begin{array}{l}\text { Barrett, } \\
\text { et al. }\end{array}$ & 2018 & $\begin{array}{c}32 \\
\text { professiona } \\
1 \text { football } \\
\text { players }(25 \\
\pm 8 \text { years })\end{array}$ & $\begin{array}{l}\text { To investigate } \\
\text { the effects of } \\
\text { playing position } \\
\text { and contextual } \\
\text { factors on the } \\
\text { internal load } \\
\text { experienced } \\
\text { during games, } \\
\text { measured via } \\
\text { differential } \\
\text { ratings of } \\
\text { perceived } \\
\text { exertion (dRPE) }\end{array}$ & $\begin{array}{l}\text { The entire season } \\
\text { was analyzed ( } 38 \\
\text { games in total) }\end{array}$ & $\begin{array}{l}\text { dRPE CR- } \\
\text { 100, a.u.: } \\
\text { RPE-T } \\
\text { (cognitive } \\
\text { demand) }\end{array}$ & $\begin{array}{l}\text { dRPE CR- } \\
\text { 100, a.u.: } \\
\text { RPE, RPE- } \\
\text { B } \\
\text { (dyspnea), } \\
\text { RPE-L } \\
\text { (muscular } \\
\text { effort of the } \\
\text { lower } \\
\text { body) }\end{array}$ \\
\hline $\begin{array}{l}\text { Coutinho } \\
\text {, et al. }\end{array}$ & 2018 & $\begin{array}{c}10 \text { amateur } \\
\text { football } \\
\text { players } \\
(13,7 \pm 0,5 \\
\text { years })\end{array}$ & $\begin{array}{l}\text { To examine the } \\
\text { effect of } \\
\text { additional } \\
\text { mental and } \\
\text { muscular } \\
\text { fatigue in } \\
\text { physical and } \\
\text { tactical } \\
\text { behavior in } \\
\text { football. }\end{array}$ & $\begin{array}{l}\text { Three situations of } \\
5 \times 5 \mathrm{SSG}, \text { random } \\
\text { order (3x6' - 3' } \\
\text { pause, for each } \\
\text { condition): } \\
\text { 1) Normal condition } \\
\text { 2) Additional } \\
\text { muscular fatigue } \\
\text { (previous task of } \\
\text { repeated direction } \\
\text { changes, RCOD) } \\
\text { 3) Additional mental } \\
\text { fatigue (Stroop } \\
\text { color-word task of } \\
\text { 30' before the SSG) }\end{array}$ & $\begin{array}{l}\text { Mental } \\
\text { fatigue } \\
\text { (MF) 100- } \\
\text { mm VAS } \\
\text { a.u. }\end{array}$ & $\begin{array}{l}\text { CR-10 RPE } \\
\text { a.u. }\end{array}$ \\
\hline
\end{tabular}

\begin{tabular}{|c|c|c|c|}
\hline $\begin{array}{l}\text { Qualitative } \\
\text { passing precision } \\
\text { (observational) }\end{array}$ & $\begin{array}{l}\text { During the task: } \\
\text { Passing } \\
\text { precision } \\
\text { After repetition: } \\
\text { NASA-TLX, } \\
\text { SAM and STAI }\end{array}$ & $\begin{array}{l}\text { The mental fatigue is } \\
\text { significantly greater in } \\
\text { the ML condition than in } \\
\text { the ACM. This } \\
\text { difference provokes a } \\
\text { decrease of the precision. } \\
\text { Both frustration and } \\
\text { subjective anxiety } \\
\text { predict passing } \\
\text { performance. } \\
\text { There is a tendency for } \\
\text { the performance to } \\
\text { improve over the course } \\
\text { of the test. }\end{array}$ & $\begin{array}{l}\text { The presence of the } \\
\text { physical load } \\
\text { simultaneous to the } \\
\text { mental load had a } \\
\text { negative effect on } \\
\text { precision. The emotional } \\
\text { states in ML condition } \\
\text { predicted the } \\
\text { performance in the } \\
\text { motor task. }\end{array}$ \\
\hline $\begin{array}{l}\text { Playing position } \\
\text { and level of } \\
\text { opponents }\end{array}$ & $\begin{array}{l}\text { 15'-30' post } \\
\text { game: dRPE }\end{array}$ & $\begin{array}{l}\text { The wings reported a } \\
\text { substantially higher } \\
\text { dRPE in comparison to } \\
\text { the rest of the positions. } \\
\text { Substantially higher } \\
\text { RPE-T were registered } \\
\text { in the games played } \\
\text { against the best teams in } \\
\text { comparison to the rest. }\end{array}$ & $\begin{array}{l}\text { Significant differences in } \\
\text { dRPE were observed } \\
\text { between different } \\
\text { playing positions, with } \\
\text { the wings being the } \\
\text { players who assume the } \\
\text { greatest load. The RPE-T } \\
\text { increases when the game } \\
\text { is against the top teams } \\
\text { in the league. }\end{array}$ \\
\hline
\end{tabular}

GPS Variables: Physical variables (Total distance, High ratio, Low ratio, Acc., Dec.) and position variables (Dyads distance, ApEn, Stretch Index, Longitudinal Sync and Lateral Sync) significantly greater in

During the task: ce provokes a

After repetition: subjective anxiety

NASA-TLX,

predict pass

There is a tendency for

the performance to

improve over the course

of the test.

Mental fatigue increases the low ratio, the number of acc. and the

longitudinal sync and

provokes a decrease of

the distance covered at

During the task: high intensities. The

physical profile during

physical profile during
the task is more affected

Pre - post task:

VAS MF, RPE

under mental fatigue

conditions. Mental

fatigue provokes a

decrease of the

longitudinal sync, stretch

index and dyads

distance. precision Both frustration and
The improvement of the levels of longitudinal synchronization after muscular fatigue, suggests the use of tactical tasks after intense exercises. Mental fatigue is the kind of fatigue that most decreases the physical so high intensity training is directly affected. performance of the task, 
Three sets of 10 free throws were

performed, with active recovery between them, and carrying out the following task: a) Oddball contro task

b) Experimental ask: 2-back task (Cognitive Load
medium-high)

To examine the effect of playing games against different rivals on pre-game 12 professiona

Arruda, 2017

salivary

testosterone

concentration

(T),

$(18,6 \pm 0,5$

years)

precompetitive anxiety and preand post-game ortisol

concentration

(C)
Three games at

\section{home against three} competitive level

were analyzed

(Difficult, 1st - 3rd ranked, HM;

Medium, 4th - 6th

MM; Easy, 7th

0th; EM) and a

(IS)

(TS)

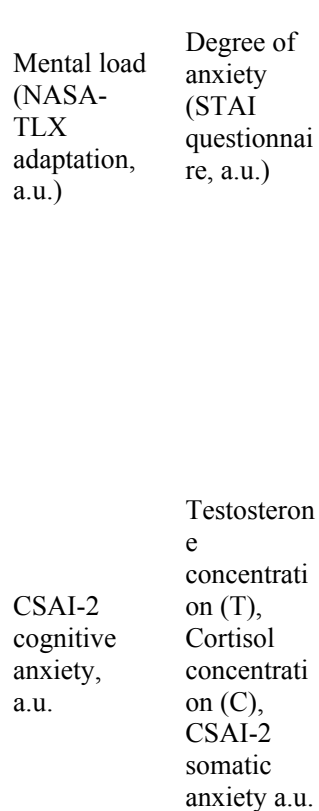

Free throw efficiency (num. of shots,

scores/failed

throws and $\%$

scores)
Statistically significan

differences in the

During the task: average NASA-TLX

Free throw scores were found

between the control

group and experi

At the end of group and experimental

the task: $\quad$ in the experimental

group exhibited worse

free throw performance

than the participants in

the control group.

The concentration of $\mathrm{T}$

(pre) is significantly

lower in the training

situations than in the

Before the start

of the

games. A significant

change of $\mathrm{C}$ (pre and

post) in all conditions

Saliva samples was observed. A higher

( $\mathrm{T}$ and $\mathrm{C}$ ) and $\mathrm{C}$ (pre) in HM was also

CSAI-2

After the

game/training:

Saliva sample

( $\mathrm{T}$ and $\mathrm{C}$ ) and

CSAI-2

EM, as wed to

TS and EM, as well as a

higher HM C (post) in

comparison to EM, MM

anxiety is lower in EM

than in MM or HM. The

cognitive anxiety

increases exponentially,

more than the somatic,

depending on the rival.

There is a negative

influence of mental

fatigue on precision

bilities, such as the

basketball free throw.

The results suggest that playing against a high

evel opponent can cause

a higher level of

psychobiological stress,

probably because the

level of the opponent can

be perceived as a threat

determined hierarchy. 


\begin{tabular}{|c|c|c|c|c|c|c|c|c|c|}
\hline $\begin{array}{l}\text { Coutinho } \\
\text {, et al. }\end{array}$ & 2017 & $\begin{array}{c}12 \text { amateur } \\
\text { football } \\
\text { players } \\
(15,9 \pm 0,8 \\
\text { years })\end{array}$ & $\begin{array}{l}\text { To identify the } \\
\text { effects of } \\
\text { mental fatigue } \\
\text { and the } \\
\text { modification of } \\
\text { additional } \\
\text { reference lines } \\
\text { in the physical } \\
\text { and tactical } \\
\text { performance of } \\
\text { the players } \\
\text { during SSG of } \\
\text { football. }\end{array}$ & $\begin{array}{l}\text { Four situations of } \\
6 \text { 6s6 SSG, with } \\
\text { previous work } \\
\text { (control task or } \\
\text { motor coordination } \\
\text { work to induce } \\
\text { mental fatigue). } \\
\text { Comparison of the } \\
\text { performance in } 4 \\
\text { conditions: 1) MF vs } \\
\text { no MF, normal field } \\
\text { (MEN) 2) MF vs } \\
\text { MF, field with } \\
\text { additional reference } \\
\text { lines (\#MEN) 3) no } \\
\text { MF vs MF, normal } \\
\text { field (CTR) 4) no } \\
\text { MF vs no MF, field } \\
\text { with additional } \\
\text { reference lines } \\
\text { (\#CTR) }\end{array}$ & $\begin{array}{l}\text { Mental } \\
\text { fatigue } \\
\text { (MF) 100- } \\
\text { mm VAS } \\
\text { a.u. }\end{array}$ & $\begin{array}{l}\text { CR-10 RPE } \\
\text { a.u. }\end{array}$ & $\begin{array}{l}\mathrm{CMJ}(\mathrm{cm}) \text {, } \\
\text { positional and } \\
\text { physical data with } \\
\mathrm{GPS}(\mathrm{m}, \mathrm{m} / \mathrm{s})\end{array}$ & $\begin{array}{l}\text { Pre task } \\
\text { cont./exp.: VAS } \\
\text { MF, RPE and } \\
\text { CMJ } \\
\text { Post task } \\
\text { cont./exp. (pre } \\
\text { SSG): VAS } \\
\text { MF, RPE and } \\
\text { CMJ } \\
\text { During SSG: } \\
\text { GPS } \\
\text { Post SSG: VAS } \\
\text { MF and RPE }\end{array}$ & $\begin{array}{l}\text { After the experimental } \\
\text { task, higher values were } \\
\text { found in MF, VAS and } \\
\text { RPE than in the control } \\
\text { condition. MEN showed } \\
\text { an increase of RPE in } \\
\text { comparison to CTR. The } \\
\text { CTR condition provokes } \\
\text { an improvement if GPS } \\
\text { positional variables in } \\
\text { comparison to MEN. } \\
\text { Adding the reference } \\
\text { lines to the field } \\
\text { provokes a deterioration } \\
\text { of the physical GPS } \\
\text { variables and an increase } \\
\text { in RPE. Furthermore, } \\
\text { adding them in MF } \\
\text { situations provokes a } \\
\text { deterioration of the } \\
\text { positional GPS variables. }\end{array}$ \\
\hline $\begin{array}{l}\text { Vallés, et } \\
\text { al. }\end{array}$ & 2017 & $\begin{array}{c}12 \\
\text { professiona } \\
1 \text { basketball } \\
\text { players } \\
(21,91 \pm \\
4,81 \text { years })\end{array}$ & $\begin{array}{l}\text { To analyze the } \\
\text { technical- } \\
\text { tactical training } \\
\text { load assessment } \\
\text { (VSC) and its } \\
\text { connection to } \\
\text { the parameters } \\
\text { of internal load. }\end{array}$ & $\begin{array}{l}\text { All trainings during } \\
\text { the last two months } \\
\text { of competition were } \\
\text { analyzed (Women's } \\
\text { league). }\end{array}$ & $\begin{array}{l}\text { VSC test } \\
\text { items: } \\
\text { competitive } \\
\text { load and } \\
\text { cognitive } \\
\text { implication } \\
\text { (scale } 0 \text { - 5) } \\
\text { a.u. }\end{array}$ & $\begin{array}{l}\text { CR-10 RPE } \\
\text { a.u. and } \\
\text { TQR }\end{array}$ & $\begin{array}{l}\text { VSC test items: } \\
\text { Degree of } \\
\text { obstacle, task } \\
\text { density, num. of } \\
\text { participants and } \\
\text { game field. }\end{array}$ & $\begin{array}{l}\text { During training: } \\
\text { subjective } \\
\text { assessment of } \\
\text { the load } \\
\text { 20' post } \\
\text { training: RPE } \\
\text { The day after } \\
\text { training: TQR }\end{array}$ & $\begin{array}{l}\text { Except for the degree of } \\
\text { obstacle of the task, the } \\
\text { VSC scale shows a high } \\
\text { correlation with the RPE. } \\
\text { There are no correlations } \\
\text { between the VSC scale } \\
\text { and the TQR. The task } \\
\text { density explains } 91,4 \% \\
\text { of the RPE. }\end{array}$ \\
\hline $\begin{array}{l}\text { Veness et } \\
\text { al. }\end{array}$ & 2017 & $\begin{array}{c}10 \\
\text { professiona } \\
1 \text { cricket } \\
\text { players } \\
(21 \pm 8 \\
\text { years })\end{array}$ & $\begin{array}{l}\text { To investigate } \\
\text { the acute effects } \\
\text { of a mentally } \\
\text { exhausting task } \\
\text { on cricket- } \\
\text { relevant } \\
\text { physical and } \\
\text { technical tasks. }\end{array}$ & $\begin{array}{l}\text { Three specific } \\
\text { physical tests were } \\
\text { carried out in three } \\
\text { different sessions: } \\
\text { Cricket run-two test, } \\
\text { Batak lite reaction } \\
\text { time test and Yo- } \\
\text { Yo-IR1 test; } \\
\text { preceded for 30' by a } \\
\text { control task or a } \\
\text { Stroop task (induces } \\
\text { MF) }\end{array}$ & $\begin{array}{l}\text { Mental } \\
\text { fatigue } \\
\text { (MF) 100- } \\
\text { mm VAS } \\
\text { a.u. }\end{array}$ & $\begin{array}{l}\text { CR-10 RPE } \\
\text { a.u., } \\
\text { Motivation } \\
\text { 100-mm } \\
\text { VAS a.u. }\end{array}$ & $\begin{array}{l}\text { Results obtained } \\
\text { in the specific } \\
\text { technical and } \\
\text { physical tests }\end{array}$ & $\begin{array}{l}\text { Before the task: } \\
\text { VAS MF, VAS } \\
\text { motivation } \\
\text { After the task: } \\
\text { RPE, VAS MF }\end{array}$ & $\begin{array}{l}\text { Significant differences in } \\
\text { the perception of mental } \\
\text { fatigue were observed } \\
\text { after the treatment. The } \\
\text { specific physical Yo-Yo- } \\
\text { IR1 and Cricket run-two } \\
\text { tests, as well as the RPE, } \\
\text { were affected by MF. In } \\
\text { the case of the Batak lite } \\
\text { test, the change was } \\
\text { moderated, but their } \\
\text { performance was not } \\
\text { affected. }\end{array}$ \\
\hline
\end{tabular}

The results showed that MF affects both the capacity to use nvironmental information and the position of the players. The additional reference ines could have mproved the use of less levant information to uide actions during the MEN condition. The motor coordination task induces a similar MF to the levels reported in previous studies using Stroop tasks.

The results revealed tha the VSC scale shows a high correlation with the RPE, but not with the TQR. This indicates that the VSC can be a good tool to calculate the internal load in basketball.

The mental fatigue induced by a Stroop task significantly affects ricket-relevant technical and physical performance. 


\begin{tabular}{|c|c|c|c|c|c|c|c|c|c|}
\hline & & & & & & חार & $\begin{array}{l}\text { GPS Variables: } \\
\text { Velocity zones, } \\
\text { total distance, }\end{array}$ & $\begin{array}{l}\text { Before the task: } \\
\text { VAS MF, VAS } \\
\text { PF }\end{array}$ & $\begin{array}{l}\text { The MF and ME } \\
\text { increased significantly } \\
\text { after carrying out the } \\
\text { Stroop task, while }\end{array}$ \\
\hline . & & $\begin{array}{c}20 \\
\text { professiona } \\
1 \text { football }\end{array}$ & $\begin{array}{l}\text { To assess the } \\
\text { effects of } \\
\text { mental fatigue }\end{array}$ & $\begin{array}{l}\text { Two sessions of } \\
5 \text { vs5 SSG without } \\
\text { goalkeepers }\left(2 \times 77^{\prime}, 1^{\prime}\right. \\
\text { rec), with a }\end{array}$ & $\begin{array}{l}\text { Mental } \\
\text { fatigue } \\
\text { (MF) 100- } \\
\text { mm VAS }\end{array}$ & $\begin{array}{l}\text { CR-10 RPE } \\
\text { a.u., } \\
\text { Motivation } \\
\text { (M) 100- } \\
\text { mm VAS }\end{array}$ & $\begin{array}{l}\text { repeated sprints } \\
\text { and accelerations. } \\
\% \text { passing } \\
\text { precision } \\
\text { (successful/total), }\end{array}$ & $\begin{array}{l}\text { After the task: } \\
\text { VAS MF, VAS } \\
\text { ME, VAS PF, } \\
\text { VAS M, RPE }\end{array}$ & $\begin{array}{l}\text { motivation was similar } \\
\text { in both conditions. The } \\
\text { RPE was greater in the } \\
\text { condition of mental } \\
\text { fatigue, although the HR }\end{array}$ \\
\hline & 2010 & $\begin{array}{c}\text { players } \\
(17,8 \pm 1 \\
\text { years })\end{array}$ & $\begin{array}{l}\text { and physical } \\
\text { performance in } \\
\text { SSG of football. }\end{array}$ & $\begin{array}{l}\text { preceding exposure } \\
\text { to } 30^{\prime} \text { of control or } \\
\text { Stroop task (induces } \\
\text { MF). }\end{array}$ & $\begin{array}{l}\text { a.u., Mental } \\
\text { Effort (ME) } \\
100-m m \\
\text { VAS a.u. }\end{array}$ & $\begin{array}{l}\text { a.u., } \\
\text { Physical } \\
\text { Fatigue } \\
\text { (PF) 100- } \\
\text { mm VAS } \\
\text { a.u. }\end{array}$ & $\begin{array}{l}\% \text { effective } \\
\text { challenges } \\
\text { (successful/total), } \\
\% \text { possessions } \\
\text { (positive/negative) } \\
\text { and \% } \\
\text { participations } \\
\text { (positive/negative) }\end{array}$ & $\begin{array}{l}\text { During SSG: } \\
\text { \%HR max, GPS } \\
\text { variables } \\
\text { After the SSG: } \\
\text { VAS MF, VAS } \\
\text { PF, VAS ME, } \\
\text { RPE }\end{array}$ & $\begin{array}{l}\text { was greater in the control } \\
\text { situation. The mental } \\
\text { fatigue does not have a } \\
\text { very clear effect on most } \\
\text { of the variables of } \\
\text { physical performance, } \\
\text { but it damages the } \\
\text { technical performance } \\
\text { variables. }\end{array}$ \\
\hline
\end{tabular}

The trainings of an intensive six-week period were monitored. A linear increase of the load was produced in the first three weeks and after that it was gradually reduced. of dRPE in the training for team sports.
To investigate
Mental fatigue did not affect physical

performance, despite the increase in perceived

effort. In contrast,

mental fatigue impaired offensive and defensive technical performance.

\begin{tabular}{|c|c|}
\hline $\begin{array}{l}\text { sRPE CR- } \\
\text { 100, a.u.: } \\
\text { RPE, RPE- } \\
\text { B } \\
\text { (dyspnea), } \\
\text { RPE-L } \\
\text { (muscular } \\
\text { effort in the } \\
\text { lower } \\
\text { body), } \\
\text { RPE-U } \\
\text { (muscular } \\
\text { effort in the } \\
\text { upper } \\
\text { body) }\end{array}$ & $\begin{array}{l}\text { Classification of } \\
\text { the training } \\
\text { typology: } \\
\text { HIIT (High- } \\
\text { intensity intervals } \\
\text { training, RHIE } \\
\text { (Repeated high } \\
\text { intensity efforts), } \\
\text { SkCond } \\
\text { (Conditioning } \\
\text { based on skills), } \\
\text { Skills, RT } \\
\text { (resistance task) } \\
\text { and URT (Upper } \\
\text { body resistance }\end{array}$ \\
\hline
\end{tabular}
physical task
Differences in the sRPE between sessions are observed depending on the training typology. The dRPE loads combined to explain the SRPE CR100, a.u.: RPE-T

(cognitive demands)

15 ' post session:
sdRPE

the sRPE loads. The

strongest associations are found between: sRPE-L for HIIT, sRPE-B for RHIE, sRPE-U for RT and sRPE-T for Velocity and Skills.
The dRPE can provide a detailed quantification of the internal load during training activities. The knowledge of the connections between sRPE and dRPE can isolate the specific perceptive demands of the different training methods. 


\begin{tabular}{|c|c|c|c|c|c|c|c|c|c|c|}
\hline $\begin{array}{l}\text { Smith et } \\
\text { al. } \\
\text { (Study 2) }\end{array}$ & 2016 & $\begin{array}{c}14 \text { amateur } \\
\text { football } \\
\text { players } \\
(19,6 \pm 3,5 \\
\text { years })\end{array}$ & $\begin{array}{l}\text { To investigate } \\
\text { the effects of } \\
\text { mental fatigue } \\
\text { on technical } \\
\text { performance } \\
\text { evaluated via } \\
\text { football-specific } \\
\text { tests }\end{array}$ & $\begin{array}{l}\text { Two sessions of } \\
\text { football-specific } \\
\text { technical tests: } \\
\text { LSPT } \\
\text { (Loughborough } \\
\text { specific pass test) } \\
\text { and LSST } \\
\text { (Loughborough } \\
\text { specific shot test). } \\
\text { These were } \\
\text { preceded by two 30' } \\
\text { situations, a control } \\
\text { and a Stroop task } \\
\text { (induces mental } \\
\text { fatigue) }\end{array}$ & $\begin{array}{l}\text { Mental } \\
\text { fatigue } \\
\text { (MF) 100- } \\
\text { mm VAS } \\
\text { a.u., Mental } \\
\text { Effort (ME) } \\
\text { 100-mm } \\
\text { VAS a.u. }\end{array}$ & $\begin{array}{l}\text { Motivation } \\
\text { (M) 100- } \\
\text { mm VAS } \\
\text { a.u. }\end{array}$ & $\begin{array}{l}\text { Results obtained } \\
\text { in the football- } \\
\text { specific technical } \\
\text { tests }\end{array}$ & $\begin{array}{l}\text { Before the task: } \\
\text { VAS MF, VAS } \\
\text { M, VAS ME } \\
\text { After the task: } \\
\text { VAS MF, VAS } \\
\text { ME, Test results }\end{array}$ & $\begin{array}{l}\text { MF and ME increased } \\
\text { significantly after } \\
\text { carrying out the Stroop } \\
\text { task, although } \\
\text { motivation was similar } \\
\text { in both conditions. The } \\
\text { performance time in } \\
\text { LSPT did not vary } \\
\text { between conditions, but } \\
\text { the penalization time } \\
\text { (errors) increased } \\
\text { significantly in the } \\
\text { condition of MF. MF } \\
\text { also provokes a decrease } \\
\text { of the velocity of throw } \\
\text { and precision in LSST }\end{array}$ & $\begin{array}{l}\text { Mental fatigue damages } \\
\text { football-specific } \\
\text { technical performance. }\end{array}$ \\
\hline $\begin{array}{l}\text { Gabbett } \\
\text { et al. }\end{array}$ & 2010 & $\begin{array}{c}16 \\
\text { professiona } \\
\text { 1 rugby } \\
\text { players } \\
(17,3 \pm 0,9 \\
\text { years })\end{array}$ & $\begin{array}{l}\text { To investigate } \\
\text { the } \\
\text { physiological, } \\
\text { cognitive and } \\
\text { skill demands of } \\
\text { "on-side" and } \\
\text { "off-side" } \\
\text { games in elite } \\
\text { rugby players }\end{array}$ & $\begin{array}{l}\text { Two 8' 8vs8 SSG } \\
\text { sessions, in random } \\
\text { order. } \\
\text { - "off-side" SSG } \\
\text { (passing the ball to a } \\
\text { player that is offside } \\
\text { is allowed) } \\
\text { - "on-side" SSG (the } \\
\text { ball can only be } \\
\text { passed to the players } \\
\text { that are onside) }\end{array}$ & $\begin{array}{l}\text { Cognitive } \\
\text { RPE a.u. }\end{array}$ & $\begin{array}{l}\text { Heart Rate } \\
\text { and RPE- } \\
10 \text { a.u. }\end{array}$ & $\begin{array}{l}\text { GPS variables: } \\
\text { total distance, } \\
\text { relative distance, } \\
\text { accelerations (in } \\
\text { three levels), } \\
\text { velocity (in five } \\
\text { levels) and } \\
\text { recovery (time, in } \\
\text { three levels) } \\
\text { Technical } \\
\text { variables (well or } \\
\text { poorly executed): } \\
\text { passes, receptions, } \\
\text { disposal } \\
\text { efficiency and } \\
\text { involvements } \\
\text { (objective of the } \\
\text { game) }\end{array}$ & $\begin{array}{l}\text { During the task: } \\
\text { GPS variables, } \\
\text { technical } \\
\text { variables and } \\
\text { HR } \\
\text { When the task } \\
\text { ends: RPE and } \\
\text { Cog.RPE }\end{array}$ & $\begin{array}{l}\text { "Off-side" games have a } \\
\text { greater amount of } \\
\text { involvements, passes and } \\
\text { effective passes. } \\
\text { Moreover, they also } \\
\text { provoke a greater total } \\
\text { covered distance, and } \\
\text { increase minor and } \\
\text { moderate accelerations } \\
\text { as well as the distance } \\
\text { covered at low, medium } \\
\text { and high velocities. } \\
\text { Significant differences in } \\
\text { disposal efficiency were } \\
\text { not found. In "off-side" } \\
\text { games recovery is lower. } \\
\text { Cog. RPE is lower for } \\
\text { "on-side" games. }\end{array}$ & $\begin{array}{l}\text { The results show that } \\
\text { "off-side" games provide } \\
\text { a greater physiological } \\
\text { and skills demand than } \\
\text { "on-side" games. For this } \\
\text { reason, they are a good } \\
\text { tool to develop physical } \\
\text { conditioning and } \\
\text { technical skills. Even so, } \\
\text { "on-side" games show a } \\
\text { greater cognitive load. }\end{array}$ \\
\hline
\end{tabular}




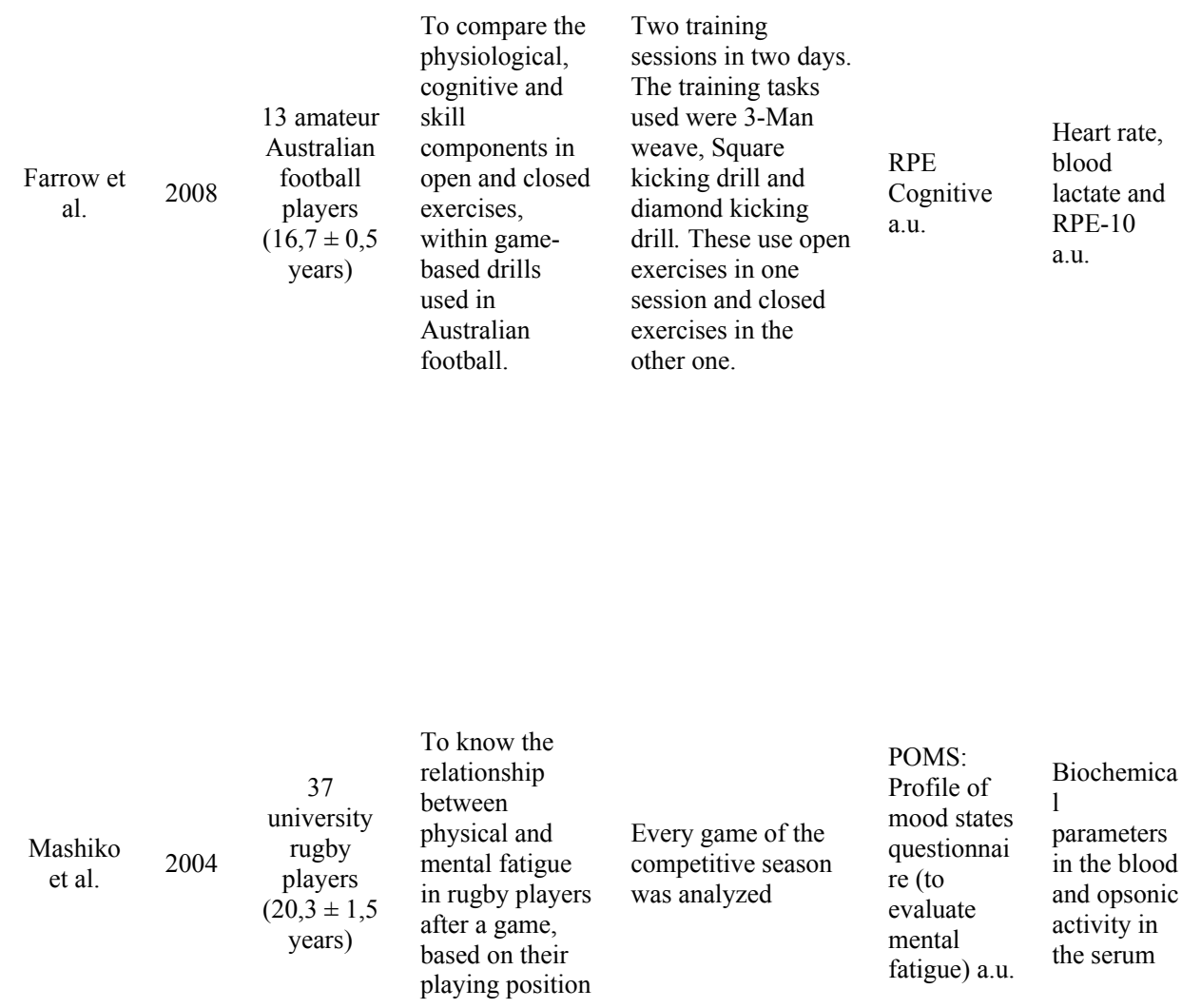

Two of the three open exercises were more demanding in terms of the total covered distance, RPE and During the task: relative intensity. All the technical efforts of moderate variables and HR GPS variables and technical variables

At the end of the task: RPE,

lactate and Cog.RPE the concentration of lactate were not found.

The HR was greater in

the open format of the third exercise. The open
The open exercises were generally more cognitively and physically demanding than the closed ones,

commonly used in Australian football. exercises were more technically demanding. Higher cognitive load scores were obtained in the open exercises.

Differences were not observed in the changes in the biochemical parameters, except for ureic nitrogen in blood,

between forwards and $3 / 4$. In regards with the

All data was collected twice: in the morning on the day of the match

(fasting condition) and
right after the match correlation between mental and physica fatigue, in the forwards, the changes in the POMS scores show a positive

correlation with the

crever on withes of musculos

In the $3 / 4$ the changes in the POMS scores show positive correlation with the changes in the levels of the parameters related to the lipids.
Open exercises should be prescribed to obtain greater cognitive and physical training loads in a game-specific context.

The exercise load differs depending on the

position played during the rugby game. It can cause important connection between mental and physical fatigue. 
Table 2 (on next page)

Managing of cognitive load with physiological indicators 
1

\begin{tabular}{|c|c|c|c|c|c|c|c|c|c|c|}
\hline Author & Year & n. & Objective & Task & $\begin{array}{c}\text { Cognitive } \\
\text { Load } \\
\text { Variables }\end{array}$ & $\begin{array}{c}\text { Internal } \\
\text { Load } \\
\text { Variables }\end{array}$ & $\begin{array}{c}\text { External } \\
\text { Load } \\
\text { Variables }\end{array}$ & $\begin{array}{l}\text { Measurement } \\
\text { Period }\end{array}$ & Results & Conclusion \\
\hline $\begin{array}{l}\text { Gantois, } \\
\text { et al. }\end{array}$ & 2019 & $\begin{array}{l}20 \\
\text { professional } \\
\text { football } \\
\text { players } \\
(22,6 \pm 3,3 \\
\text { years })\end{array}$ & $\begin{array}{l}\text { To analyze } \\
\text { the effect } \\
\text { of mental } \\
\text { fatigue on } \\
\text { decision- } \\
\text { making in } \\
\text { football } \\
\text { players }\end{array}$ & $\begin{array}{l}\text { Three different tests } \\
\text { were carried out over } \\
\text { three weeks (one } \\
\text { week between } \\
\text { sessions): "Stroop } \\
\text { task", followed by a } \\
\text { warm-up and a SSG. } \\
\text { Stroop tasks: control } \\
\text { (CON), 15' ST (15ST) } \\
\text { and 30' ST (30ST) }\end{array}$ & $\begin{array}{l}\text { Heart Rate } \\
\text { Variability, } \\
\text { HRV } \\
\text { (RMSSD, } \\
\text { SDNN and } \\
\text { pNN50) } \\
\text { and } \\
\text { reaction } \\
\text { time, RT } \\
\text { (seconds) }\end{array}$ & $\begin{array}{l}\text { Urine } \\
\text { osmolality } \\
\text { (Armstrong's } \\
\text { scale), TQR } \\
\text { questionnaire } \\
\text { (Total } \\
\text { Quality of } \\
\text { Recovery, } \\
\text { a.u.), CR-10 } \\
\text { sRPE a.u. }\end{array}$ & $\begin{array}{l}\text { Index of } \\
\text { Passing } \\
\text { Decision- } \\
\text { making } \\
\text { (PDM) } \\
(\%)\end{array}$ & $\begin{array}{l}\text { Pre/Post } \\
\text { Stroop Task: } \\
\text { Urine, TQR, } \\
\text { HRV, RPE } \\
\text { During SSG: } \\
\text { PDM, TR } \\
\text { 30' post SSG: } \\
\text { sRPE }\end{array}$ & $\begin{array}{l}\text { There are no significant } \\
\text { differences between HRV, } \\
\text { TQR, Urine, sRPE and the } \\
\text { different Stoop tasks. } \\
\text { All participants showed a } \\
\text { decrease of PDM in } \\
\text { conditions of } 30 \mathrm{ST} \text { in } \\
\text { comparison to } 15 \mathrm{ST} \text { and } \\
\text { CON. The RT increases } \\
\text { significantly with mental } \\
\text { fatigue. }\end{array}$ & $\begin{array}{l}\text { The mental fatigue } \\
\text { induced by the Stroop } \\
\text { task damages the decision } \\
\text { making of the football } \\
\text { players and therefore their } \\
\text { performance. }\end{array}$ \\
\hline
\end{tabular}


Table 3 (on next page)

Managing of cognitive load with behavioral indicators 
1

\begin{tabular}{|c|c|c|c|c|c|c|c|c|c|c|}
\hline Author & Year & n. & Objective & Task & $\begin{array}{c}\text { Cognitive } \\
\text { Load } \\
\text { Variables } \\
\end{array}$ & $\begin{array}{c}\text { Internal } \\
\text { Load } \\
\text { Variables } \\
\end{array}$ & $\begin{array}{c}\text { External } \\
\text { Load } \\
\text { Variables } \\
\end{array}$ & $\begin{array}{l}\text { Measurement } \\
\text { Period }\end{array}$ & Results & Conclusion \\
\hline $\begin{array}{l}\text { Gantois, } \\
\text { et al. }\end{array}$ & 2019 & $\begin{array}{l}20 \\
\text { professional } \\
\text { football } \\
\text { players } \\
(22,6 \pm 3,3 \\
\text { years })\end{array}$ & $\begin{array}{l}\text { To analyze } \\
\text { the effect of } \\
\text { mental } \\
\text { fatigue on } \\
\text { decision- } \\
\text { making in } \\
\text { football } \\
\text { players }\end{array}$ & $\begin{array}{l}\text { Three different } \\
\text { tests were carried } \\
\text { out over three } \\
\text { weeks (one week } \\
\text { between sessions): } \\
\text { "Stroop task", } \\
\text { followed by a } \\
\text { warm-up and a } \\
\text { SSG. } \\
\text { Stroop tasks: } \\
\text { control (CON), 15' } \\
\text { ST (15ST) and 30' } \\
\text { ST (30ST) }\end{array}$ & $\begin{array}{l}\text { Heart Rate } \\
\text { Variability, } \\
\text { HRV } \\
\text { (RMSSD, } \\
\text { SDNN and } \\
\text { pNN50) } \\
\text { and } \\
\text { reaction } \\
\text { time, RT } \\
\text { (seconds) }\end{array}$ & $\begin{array}{l}\text { Urine } \\
\text { osmolality } \\
\text { (Armstrong's } \\
\text { scale), TQR } \\
\text { questionnaire } \\
\text { (Total } \\
\text { Quality of } \\
\text { Recovery, } \\
\text { a.u.), CR-10 } \\
\text { sRPE a.u. }\end{array}$ & $\begin{array}{l}\text { Index of } \\
\text { Passing } \\
\text { Decision- } \\
\text { making } \\
(\text { PDM) }(\%)\end{array}$ & $\begin{array}{l}\text { Pre/Post Stroop } \\
\text { Task: Urine, } \\
\text { TQR, HRV, RPE } \\
\text { During SSG: } \\
\text { PDM, TR } \\
\text { 30' post SSG: } \\
\text { sRPE }\end{array}$ & $\begin{array}{l}\text { There are no significant } \\
\text { differences between } \\
\text { HRV, TQR, Urine, sRPE } \\
\text { and the different Stoop } \\
\text { tasks. } \\
\text { All participants showed a } \\
\text { decrease of PDM in } \\
\text { conditions of } 30 \text { ST in } \\
\text { comparison to } 15 \mathrm{ST} \text { and } \\
\text { CON. The RT increases } \\
\text { significantly with mental } \\
\text { fatigue. }\end{array}$ & $\begin{array}{l}\text { The mental fatigue } \\
\text { induced by the Stroop } \\
\text { task damages the } \\
\text { decision making of the } \\
\text { football players and } \\
\text { therefore their } \\
\text { performance. }\end{array}$ \\
\hline $\begin{array}{l}\text { Moreira, } \\
\text { et al. }\end{array}$ & 2018 & $\begin{array}{l}32 \text { high } \\
\text { level } \\
\text { basketball } \\
\text { players } \\
(15,2 \pm 1,2 \\
\text { years })\end{array}$ & $\begin{array}{l}\text { To examine } \\
\text { the effect of } \\
\text { mental effort } \\
\text { on } \\
\text { physiological } \\
\text { changes and } \\
\text { technical } \\
\text { performance } \\
\text { in SSG. }\end{array}$ & $\begin{array}{l}\text { Two } 4 \times 4 \text { SSG } \\
\text { trainings, separated } \\
\text { by a week ( } 4 \times 2 \text { ' } 30 \\
\text { - 1' pause). They } \\
\text { are preceded by } \\
\text { two situations: } \\
\text { 1) Control: } 30^{\prime} \\
\text { control treatment } \\
\text { 2) Experimental: } \\
\text { 30' Stroop Task }\end{array}$ & $\begin{array}{l}\text { Reaction } \\
\text { time, RT } \\
\text { (seconds) }\end{array}$ & $\begin{array}{l}\text { RPE session } \\
\text { (CR-10, } \\
\text { a.u.), HR, } \\
\text { saliva } \\
\text { samples: } \\
\text { concentration } \\
\text { of } \\
\text { testosterone } \\
\text { (T), cortisol } \\
\text { (C) and } \\
\text { alpha- } \\
\text { amylase } \\
\text { (sAA) }\end{array}$ & $\begin{array}{l}\text { Performance } \\
\text { parameters } \\
\text { through } \\
\text { video } \\
\text { analysis. }\end{array}$ & $\begin{array}{l}\text { Pre task } \\
\text { cont./exp.: Saliva } \\
\text { During the task } \\
\text { cont./exp.: RT } \\
\text { Post task } \\
\text { cont./exp. (pre } \\
\text { SSG): Saliva } \\
\text { During SSG: } \\
\text { Performance } \\
\text { parameters and } \\
\text { HR } \\
\text { Post SSG: Saliva } \\
\text { (15' post) and } \\
\text { RPE (30' post) }\end{array}$ & $\begin{array}{l}\text { The RT decreased } \\
\text { significantly during the } \\
\text { test, except during the last } \\
5 \text { '. There's a direct } \\
\text { correlation between the } \\
\text { number of turnovers and } \\
\text { the experimental task. } \\
\text { Thera are an increase of } \\
\text { the concentrations of T } \\
\text { and sAA from the pre- } \\
\text { control treatment to the } \\
\text { post SSG. There is little } \\
\text { difference between the } \\
\text { treatments regarding the } \\
\text { sRPE and the HR. }\end{array}$ & $\begin{array}{l}\text { Mental fatigue induced } \\
\text { by a Stroop task affects } \\
\text { the performance of the } \\
\text { task negatively. This } \\
\text { also provokes a } \\
\text { modulation of the } \\
\text { endocrine response (it } \\
\text { alleviates the } \\
\text { concentrations of T and } \\
\text { sAA, in comparison to } \\
\text { the control condition). } \\
\text { Between sRPE and HR } \\
\text { we do not see very clear } \\
\text { differences. }\end{array}$ \\
\hline $\begin{array}{l}\text { Scanlan } \\
\text { et al. }\end{array}$ & 2013 & $\begin{array}{l}12 \\
\text { basketball } \\
\text { players } \\
(25,9 \pm 6,7 \\
\text { years })\end{array}$ & $\begin{array}{l}\text { To determine } \\
\text { the influence } \\
\text { of physical } \\
\text { and } \\
\text { cognitive } \\
\text { factors in the } \\
\text { development } \\
\text { of reactive } \\
\text { agility in } \\
\text { basketball } \\
\text { players. }\end{array}$ & $\begin{array}{l}\text { Three basketball- } \\
\text { specific tests were } \\
\text { carried out: } \\
\text { multiple sprint test, } \\
\text { Change of } \\
\text { Direction Speed } \\
\text { Test and Reactive } \\
\text { Agility Test }\end{array}$ & $\begin{array}{l}\text { Reaction } \\
\text { time and } \\
\text { decision- } \\
\text { making } \\
\text { time (s) }\end{array}$ & & $\begin{array}{l}5,10, \text { and } \\
20 \mathrm{~m} \text { sprint } \\
\text { times (s), } \\
\text { max. V } \\
(\mathrm{m} / \mathrm{s}) \text {, } \\
\text { Reactive } \\
\text { agility time } \\
\text { (s), closed- } \\
\text { skill agility } \\
\text { time (s) }\end{array}$ & $\begin{array}{l}\text { All measures } \\
\text { were carried out } \\
\text { during the } \\
\text { basketball- } \\
\text { specific tests }\end{array}$ & $\begin{array}{l}\text { The simple and stepwise } \\
\text { regression analyses } \\
\text { determined the individual } \\
\text { influence of each } \\
\text { predictive variable and } \\
\text { the best predictive model } \\
\text { for reactive agility time. } \\
\text { Through the stepwise } \\
\text { model, the reaction time } \\
\text { is identified as the only } \\
\text { predictive variable. }\end{array}$ & $\begin{array}{l}\text { The cognitive measures } \\
\text { had the greatest } \\
\text { influence on the reactive } \\
\text { agility performance of } \\
\text { the basketball players }\end{array}$ \\
\hline
\end{tabular}

